\title{
The Political Speech of Charities in the Face of Citizens United: A Defense of Prohibition
}

Roger Colinvaux

Follow this and additional works at: https://scholarlycommons.law.case.edu/caselrev

Part of the Law Commons

\section{Recommended Citation}

Roger Colinvaux, The Political Speech of Charities in the Face of Citizens United: A Defense of Prohibition, 62 Case W. Rsrv. L. Rev. 685 (2012)

Available at: https://scholarlycommons.law.case.edu/caselrev/vol62/iss3/12

This Article is brought to you for free and open access by the Student Journals at Case Western Reserve University School of Law Scholarly Commons. It has been accepted for inclusion in Case Western Reserve Law Review by an authorized administrator of Case Western Reserve University School of Law Scholarly Commons. 


\title{
The Political SPEech of CHARITIES IN THE FACE OF CITIZENS UNITED: A DEFENSE OF PROHIBITION
}

\author{
Roger Colinvaux
}

CONTENTS

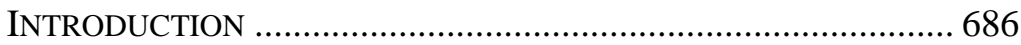

I. HISTORICAL BACKGROUND OF A NOBLE RULE .................. 689

A. A Brief History of the Prohibition: A Noncontroversial Rule................................................... 690

B. Legislative Developments after Enactment .................... 697

C. Criticisms of and Reasons for the Rule ......................... 699

II. Does CITIZENS UNITED CONDEMN THE POLITICAL

ACTIVITIES PROHIBITION? .............................................. 707

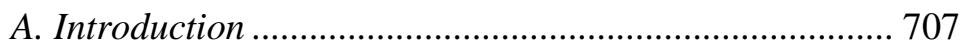

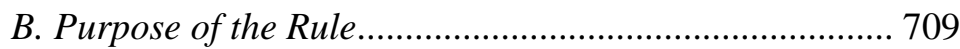

1. Purpose of Section 501(c)(3) is to Define Charity for Tax Purposes ...................................................... 709

2. Purpose of the Rule Viewed as Part of the TaxExemption System

$\dagger$ Roger Colinvaux, Associate Professor, Columbus School of Law, The Catholic University of America; Legislation Counsel, Joint Committee on Taxation, U.S. Congress, 2001-2008. Copyright Roger Colinvaux. My thanks to Harvey Dale and Jill Manny for asking me to write and present this Article for the National Center on Philanthropy and the Law at the NYU School of Law in connection with the October 2010 conference "Nonprofit Speech in the 21st Century: Time for a Change?" My thanks to Harvey Dale (again) and to Miriam Galston for their thoughtful comments on the Article, and to the other conference participants. An acknowledgment of Professor Laura Chisolm, whose thoughtful and inspired work continues to inform and provoke. And a dedication to my wife, Julie, a paragon. Thanks also to Lindsey Cloud for research assistance. A prior version of this article was available for download on the Social Science Research Network under the title Citizens United and the Political Speech of Charities. 
3. Purpose and Institutional Considerations ................. 715

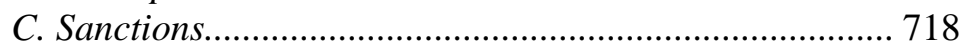

D. A Ban on Speech............................................................ 721

E. Identity Discrimination ...................................................... 723

F. Existing Jurisprudence Supports the Political Activities Prohibition..................................................... 725

1. The Rules of Speiser, Cammarano, and TWR ........... 726

2. The Speiser-Cammarano-TWR Trilogy Discussed. .. 728

III. CAUTIONARY NOTES AND THE RELEVANCE OF THE CHARITABLE DEDUCTION ................................................... 732

A. Purpose to Penalize Speech............................................... 733

B. The Penalty Effect and the Charitable Deduction: Significance and Sufficiency of an Alternate Channel .. 733

C. Implications of Reliance on Constitutional Conditions

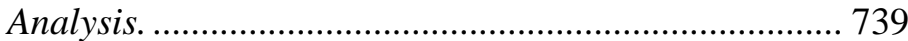

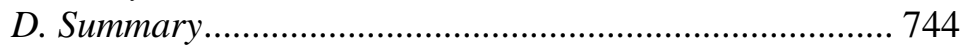

IV. AlteRnatiVES TO THE STATUS QUO ARE WANTING.......... 744

A. One Extreme: Congress May Not Restrict the Political Activity of Charitable Organizations.............. 744

B. Assuming Change to the Prohibition, Some Limit Should Be Contemplated ............................................. 746

C. Taxing Speech: The Most Plausible Limitation.............. 750

D. Much Ado About Nothing? It Depends on the

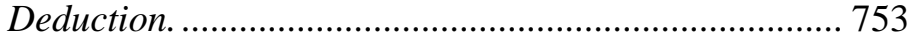

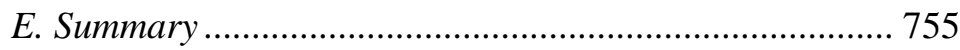

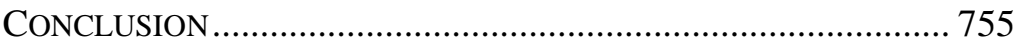

\section{INTRODUCTION}

The rule that charitable organizations may not "participate in, or intervene in ... any political campaign" is hardly a secret. Since its introduction as part of the Internal Revenue Code in 1954, section 501(c)(3)'s "Political Activities Prohibition,"2 as it is often called, has been the subject of considerable scholarly debate, practical concern,

1 I.R.C. § 501(c)(3) (2006). For convenience, the term "charitable organizations" is used here to refer to any of the organization types described in section 501(c)(3), including educational, religious, scientific, and literary.

2 See, e.g., David A. Wimmer, Curtailing the Political Influence of Section 501(c)(3) Tax-Exempt Machines, 11 VA. TAX REV. 605, 622 (1992) (calling section 501(c)(3)'s rule that charitable organizations cannot participate in political campaigns the "Political Activities Prohibition"). 
and occasional political wrangling. Although the contours of the rule may be imprecise, and enforcement by the IRS uneven - resulting in frustration for some - arguably the rule has stood the test of time. Like it or not, understand it or not, it is an embedded characteristic of the charitable sector that charity and political activity are by law incompatible.

As a practical matter, the "Political Activities Prohibition" or "Rule" means that charities may not become partisan, or agents of propaganda. ${ }^{3}$ The Rule keeps charitable institutions outside of the political sphere. Charities are allowed a voice on issues, but may not become political actors or unbalanced purveyors of opinion. Of course, as Aristotle said long ago, "man is by nature a political animal." "Thus, a rule that keeps associations of persons from speaking politically is bound to bump up against primal forces from time to time - and so it has proved. But, despite occasional pressure on the Rule, there has been little realistic chance of reversing this defining characteristic of the charitable "independent" sector by Congress or the courts.

One reason the Rule has lasted is that, by and large, it has been uncontroversial. There have been some loud voices raised in resistance, but little concrete action. ${ }^{5}$ Another reason the Rule has survived may be because, to a certain extent, it was redundant. Absent the Rule, charities still would have faced a prohibition on some of their political activities under campaign finance laws, which, until recently, had long provided that corporations, including charitable corporations, could not spend money expressly advocating for or against a candidate for public office. ${ }^{6}$ Accordingly, for the most political of speech, charities faced both a tax law restriction and a campaign finance law restriction.

The Supreme Court's decision in Citizens United v. Federal Election Commission, ${ }^{7}$ however, changed the legal landscape. Citizens United held that the campaign finance rule prohibiting corporate expenditures for express advocacy $^{8}$ (or its functional

3 I.R.C. $\$ 501(\mathrm{c})(3)$.

4 ARistole, Politics And Poetics 5 (Compass Books ed., Benjamin Jowett \& Thomas Twining trans., The Viking Press 1957) (c. 350 B.C.E.).

5 See infra Part I.C for a discussion of criticisms of the Rule.

6 Labor Management Relations Act of 1947, Pub. L. No. 80-101, § 304, 61 Stat. 136, 159 (codified at 2 U.S.C. $\$ 251$ (Supp. I 1947)) (repealed 1948).

7130 S. Ct. 876 (2010).

8 Express advocacy means to use "express terms [that] advocate the election or defeat of a clearly identified candidate for federal office," such as "“vote for,' 'elect,' 'support,' 'cast your ballot for,' 'Smith for Congress,' 'vote against,' 'defeat,' [or] 'reject.'” Buckley v. Valeo, 424 U.S. 1, 44 n.52 (1976). 
equivalent) is an unconstitutional burden on free speech under the First Amendment. ${ }^{9}$ Accordingly, the tax rule now stands alone, prohibiting not only express advocacy by charitable corporations, but also other forms of political speech as defined by the Internal Revenue Service ("IRS"). ${ }^{10}$ A challenge to the constitutionality of the Political Activities Prohibition thus seems inevitable. ${ }^{11}$ Can the prohibition survive Citizens United? Should it? These are the questions addressed in this Article. ${ }^{12}$

Part I surveys the history of the political activities prohibition, emphasizing that it was not a reactionary policy, but quite considered and is supported by strong state interests. Part II analyzes Citizens United in detail. It argues that if the Supreme Court reviews the Political Activities Prohibition, Citizens United is distinguishable, and that the Political Activities Prohibition, unlike the campaign finance rule, is not a burden on speech and, therefore, is constitutional. Part III discusses cautionary notes to Part II's analysis, and explains that even if the Political Activities Prohibition is constitutionally defective, the important limitation on the charitable deduction nonetheless would survive. Regardless of the constitutionality of the Political Activities Prohibition, Part IV outlines and examines alternatives to present law, considering practical, legal, and administrative concerns with a regime that allows some political activity by charitable organizations. This Part concludes that the Political Activities Prohibition is the best option, in part because alternatives would dilute the meaning of charity and prove even more difficult to administer than present law.

As a side note, although the thrust of this Article is about the Political Activities Prohibition of section 501(c)(3), the prohibition cannot be viewed in isolation. It is closely connected to section 501(c)(3)'s lobbying limitation ${ }^{13}$ and also to provisions of the Internal

9130 S. Ct. at 886.

10 See infra note 80 and accompanying text for a description of the type of activity generally covered by the Rule.

11 One such challenge has been made, but faltered. See, e.g., Catholic Answers, Inc. v. United States, 09-CV-670-IEG (AJB), 2009 WL 3320498, at *2 (S.D. Cal. Oct. 14, 2009), aff' $d_{2}$ 09-56926, 2011 WL 2452177 (9th Cir. June 21, 2011) (dismissing plaintiff's request for a declaration that treasury regulations apply only to activities that constitute express advocacy), cert. denied, 80 U.S.L.W. 3440 (U.S. Jan. 23, 2012) (No. 11-511).

12 See also Miriam Galston, When Statutory Regimes Collide: Will Citizens United and Wisconsin Right to Life Make Federal Tax Regulation of Campaign Activity Unconstitutional?, 13 U. PA. J. CONST. L. 867, 873-74 (2011) (arguing that the Political Activities Prohibition is not likely to be held to be an unconstitutional burden). This Article generally agrees with Professor Galston's conclusion, but takes a different and supplementary approach.

13 An organization is not recognized under section 501(c)(3) unless "no substantial part of the activities of [the organization] is carrying on propaganda, or otherwise attempting, to influence legislation.” I.R.C. § 501(c)(3) (2006). 
Revenue Code (the "Code") ${ }^{14}$ that disallow ordinary and necessary business expense deductions for lobbying and political activity, ${ }^{15}$ disallow charitable contribution deductions for contributions to an organization that engages in political activity or substantial lobbying, ${ }^{16}$ and provide for the tax treatment of political organizations. ${ }^{17}$ Although full exploration of the history and relevance of these important provisions is beyond this Article's scope ${ }^{18}$ much of the discussion is relevant not just to the political activity of section 501(c)(3) organizations, but to the political and lobbying activity of tax-exempt organizations more broadly.

\section{HISTORICAL BACKGROUND OF A NOBLE RULE}

From the original federal income tax exemption for charitable organizations in $1913^{19}$ to the present, the term "political activity" has given rise to considerable confusion. Today, the term refers to activity covered by the Political Activities Prohibition of section 501(c)(3) and is distinguished from another subset of activity related to politics, namely lobbying, which carries its own separate limitation. ${ }^{20}$ Although we now readily distinguish between the two, historically the term "political activity" did not have the same technical meaning. ${ }^{21}$ Rather, references to political activity often included both lobbying and campaign activity, as if the two types were part of the same topic of concern. ${ }^{22}$ This is important because arguably, an unanswered question in 1913 was what sort of "political activity," broadly

14 Unless otherwise indicated, all references to the "Code" are to the Internal Revenue Code of 1986, as amended.

15 I.R.C. $\$ 162(\mathrm{e})$.

16 I.R.C. $\$ 170(\mathrm{c})(2)(\mathrm{D})$.

17 I.R.C. $\$ 527$.

18 For a discussion of the effect of Citizens United on the lobbying limitation, see Lloyd Hitoshi Mayer, Charities and Lobbying: Institutional Rights in the Wake of Citizens United, 10 ELECTION L.J. 407, 415 (2011) (arguing "it is highly unlikely that the Citizens United decision throws the existing federal tax law limits on lobbying by charities into immediate doubt"). For a discussion of the effect of Citizens United on non-charitable exempt organizations, see Ellen P. Aprill, Regulating the Political Speech of Noncharitable Exempt Organizations After Citizens United 10 ELECTION L.J. 363, 391 (2011) (reviewing questions raised by Citizens United regarding "limits and burdens" on noncharitable tax-exempt organizations' political speech).

19 The Tariff Act of 1913, Pub. L. No. 63-16 § II(G), 38 Stat. 114, 172.

20 See supra note 13 and accompanying text (discussing the lobbying limitation).

21 See, e.g., Elias Clark, The Limitation on Political Activities: A Discordant Note in the Law of Charities, 46 VA. L. REV. 439, 444 (1960) (writing about "political activity," to mean what today we refer to as lobbying activity, and distinguishing it from campaign activity). Also, early references to "political activity" in legislative history were broad and included lobbying. See, e.g., H.R. REP. No. 83-2681, at 18 (1954) (concluding that the laws regulating the "political activity" of charitable organizations, including lobbying and political activity, were not sufficient).

${ }^{22}$ H.R. REP. NO. 83-2681, at 95 (discussing the lobbying prohibition but using the term political activity). 
construed, was consistent with charitable tax status. In part, the statutory history of political activity and charity is a response to this question, one that fashioned distinct legal categories to limit and describe specific types of "political activity."

\section{A. A Brief History of the Prohibition: A Noncontroversial Rule}

Senator Lyndon Johnson famously inserted the Political Activities Prohibition as a Senate floor amendment to legislation that became the Internal Revenue Code of $1954 .^{23}$ There is no direct legislative history to the provision explaining Congress's reasoning. ${ }^{24}$ The Rule's abrupt passage leads many to conclude that its rationale was mostly political: Senator Johnson was attacked by a charity during his reelection campaign and used the power of his office to change the law to prohibit such attacks. ${ }^{25}$ And there is little doubt that Johnson pushed the Rule through in the heat of a political battle. Indeed, after a thorough review of the legislative record, one commentator concluded that "Johnson saw a cabal of national conservative forces, led by tax-exempt educational entities fueled by corporate donations, arrayed against him and wanted to put a stop to the meddling of these

23100 CONG. REC. 9604 (1954).

24 The direct legislative history is succinct. Senator Johnson explained to the Senate:

Mr. President, this amendment seeks to extend the provisions of section 501 of the House bill, denying tax-exempt status to not only those people who influence legislation but also to those who intervene in any political campaign on behalf of any candidate for any public office. I have discussed the matter with the chairman of the committee, the minority ranking member of the committee, and several other members of the committee, and I understand that the amendment is acceptable to them. I hope the chairman will take it to conference, and that it will be included in the final bill which Congress passes.

Id.

25 See Bruce R. Hopkins, The Law of TAX-Exempt ORganizations 603 (10th ed. 2011) ("[Senator Johnson] offered the amendment out of concern that funds provided by a charitable foundation were being used to help finance the campaign of an opponent in a primary election."); JAMES J. FISHMAN \& STEPHEN SCHWARZ, TAXATION OF NONPROFIT ORGANIZATIONS 261 (2d ed. 2006) (internal citation omitted) ("The conventional wisdom is that Senator Johnson was out to curb the activities of a Texas foundation which had provided indirect financial support to his opponent in a senatorial primary election campaign."); Oliver A. Houck, On the Limits of Charity: Lobbying, Litigation, and Electoral Politics by Charitable Organizations Under the Internal Revenue Code and Related Laws, 69 BROOK. L. REV. 1, 24 (2003) ("Commentators have explained that Senator Johnson was motivated by the activities of charities allied to his opponent in a recent campaign."); Patrick L. O'Daniel, More Honored in the Breach: A Historical Perspective of the Permeable IRS Prohibition on Campaigning by Churches, 42 B.C. L. REV. 733, 768 (2001) (noting that Johnson wanted to prohibit certain taxexempt entities from intervening in political campaigns, in part, because he "wanted to stomp out a potential threat in his own back yard"). 
foreign interlopers." ${ }^{26}$ Enactment of the Political Activities Prohibition was his weapon of choice.

Notwithstanding the circumstances of the Rule's enactment, however, the broader historical record offers a more compelling story of the origin of the Rule than the reaction of a single skillful Senator to a political problem. Although the absence of direct legislative history is accurate, a view often implicit (and sometimes explicit) in some discussions of the Rule ${ }^{27}$ is that, in part because of the abrupt fashion in which the Rule was enacted, the rationale is uncertain, and we are, for the most part, supplying reasons for Congress' actions after the fact. Importantly, here, the implication may be that the Rule was adopted ad hoc, and therefore should be changed, or if not changed, perhaps treated with less reverence than a more fully reasoned rule.

Although this is an important objection to the Rule, it overstates the significance of both the barren legislative history and Johnson's self-interest. Legislators often act with selfish motives and consistently fail fully to explain their actions for the record. But such facts do not necessarily undermine a law's broader purposes or intent. In the case of the Political Activities Prohibition, for example, the question of charity and politics did not arise suddenly in the summer

26 O’Daniel, supra note 25, at 768.

27 See, e.g., Nina J. CRimm \& LAURENCE H. Winer, Politics, TAXES, AND THE PUlPit: ProvocAtive FIRST AMENDMENT CONFLICTS 116 (2011) (footnote omitted) ("The politically expedient and partisan impetuses for the proscription on political campaign speech were perhaps a significant reason that Congress never clearly articulated a comprehensive, broadly acceptable rationale as to why the statutory ban was 'sound tax policy.' That gap left it ripe for academicians later to justify the gag rule. Their arguments necessarily are after-the-fact rationalizations and speculations, largely based on asserted public policy grounds, more than rationales supported by legislative history.”); John Simon, Harvey Dale \& Laura Chisolm, The Federal Tax Treatment of Charitable Organizations, in THE NONPROFIT SECTOR 267, 285-86 (Walter W. Powell \& Richard Steinberg eds., 2d ed. 2006) ("It is generally agreed that no cogent, consistent rationale for the various restrictions on political activity found in $\$ 501(\mathrm{c})(3)$ and related provisions can be unearthed in the legislative record of their enactment. Rather, the constraints were adopted piecemeal, often with little discussion, and, in the case of the campaigning ban, as an apparently ad hoc response to a perceived affront to the lawmakers who sponsored the bill."); Keith S. Blair, Praying for a Tax Break: Churches, Political Speech, and the Loss of Section 501(c)(3) Tax Exempt Status, 86 DENV. U. L. REV. 405, 413 (2009) (citing briefly the "little legislative history" and the "generally accepted" facts that led Johnson to introduce the amendment); Siri Mielke Buller, Lobbying and Political Restrictions on $\S$ 501(c)(3) Organizations: A Guide for Compliance in the Wake of Increased IRS Examination, 52 S.D. L. REV. 136, 143 (2007) (discussing briefly that the 1954 amendment restricting political activity was Johnson's doing and that it remains in the current code); Houck, supra note 25, at 81 ("The Internal Revenue Code restraints on the political activities of charities have been in evolution, and in dispute, for nearly a century. They represent no grand plan, but rather a design arrived at in pieces by the impulses of the moment. They have been looking for a reason since the time they first appeared, and it was half a century before Congress even attempted one. Reading their histories, one is struck by the fact that each of the limitations, in a different climate, could have come out quite differently."). 
of 1954. Rather, it was an issue that had dogged charitable tax status from the inception of the federal income tax exemption for charitable organizations.

From the beginning in 1913, there was considerable uncertainty about the relationship of charity to political activity as reflected in the common law of charitable trusts. As Professor Houck explains, "By the early twentieth century ... the English rule [on political activity] and its applications had evolved to the point where political activitylegislative or electoral, exclusive or ancillary - was fatal [to charitable status]. ${ }^{28}$ Houck also notes, however, that the majority American rule diverged from the English approach to embrace the use of political means to secure charitable ends. ${ }^{29}$ Likewise, Professor Chisolm, discussing the common law of trusts, concluded that:

[w] hat can be derived from the cases is the principle that at common law, political purposes are not charitable purposes; what the cases do not necessarily establish is that the use of political means (even arguably partisan political means) to achieve a charitable end nullifies the charitable character of that end at common law. ${ }^{30}$

Uncertainty about the relationship of political activity and charity did not take long. In 1917, Congress provided for a deduction from federal income taxes for contributions to charitable organizations. ${ }^{31}$ In order to determine which organizations were eligible to receive charitable contributions, the Treasury adopted a regulation in 1919 providing that "associations formed to disseminate controversial or partisan propaganda are not educational within the meaning of the statute." ${ }^{32}$ Although the basis for the regulation is unclear, ${ }^{33}$ it shows that the Treasury was skeptical from the beginning that partisan propaganda could be charitable activity, despite the absence of any formal restriction in the statute.

28 Houck, supra note 25 , at 5.

29 Id. at 7-8.

30 Laura Brown Chisolm, Politics and Charity: A Proposal for Peaceful Coexistence, 58 Geo. WASH. L. REV. 308, 346 (1990); see also Anne Berrill Carroll, Religion, Politics, and the IRS: Defining the Limits of Tax Law Controls on Political Expression by Churches, 76 MARQ. L. REV. 217, 252-53 (1992) (arguing that campaign intervention that furthers the organization's mission is consistent with the common law on charitable trusts).

31 War Revenue Act, Pub. L. No. 65-50, § 1201(2), 40 Stat. 300, 330 (1917).

32 T.D. 2831, 21 Treas. Dec. Int. Rev. 170, 285 (1919).

33 Houck, supra note 25 , at 9 . Houck described the early interpretive rulings of the Treasury as initially recognizing political ends as charitable before changing course and deciding that "[p]ropaganda is that which propagates the tenets or principles of a particular doctrine by zealous dissemination" and thus was not for the public benefit. Id. at 10 (quotations and citations omitted). Subsequent decisions struggled to maintain the propaganda-educational distinction. $I d$. at $10-12$ 
The distrust was not limited to the executive branch. In Slee v. Commissioner, ${ }^{34}$ Judge Learned Hand ruled that an organization formed to provide information about birth control acted contrary to its charitable tax exemption when it lobbied to change the birth control laws. ${ }^{35}$ Judge Hand famously held that "[p]olitical agitation as such is outside the statute, however innocent the aim." ${ }^{\prime 36}$

Inevitably, Congress was drawn into the debate. In 1934, Congress drew an initial line in the Code by requiring that "no substantial part" of a charitable organization's activities could be "carrying on propaganda, or otherwise attempting, to influence legislation." 37 This lobbying limitation was prompted by a charity's high profile opposition to the New Deal legislation. ${ }^{38}$ Accordingly, the response ultimately enacted was directed to legislative and not campaign activity. Congress was aware, however, of the distinction between the two subsets of "political activity." While debating the lobbying limit, the Senate in 1934 initially passed language similar to the later Johnson Amendment: to wit, that no "substantial part" of a charity's activities may be "participation in partisan politics." 39 Congress as a whole, however, considered the Senate language too broad and struck it in conference. ${ }^{40}$ Thus, the 1934 legislation severely limited one type of political activity-lobbying - but left open for another day the issue of campaign intervention. That other day came twenty years

3442 F.2d 184 (2d Cir. 1930).

35 Id. at 186.

$36 I d$. at 185 . Professor Houck described the cases that followed Slee as limiting its reach. Houck, supra note 25, at 14-15.

3726 U.S.C. § 103(6) (1934) (codified as amended at I.R.C. § 501(c)(3) (2006)); see HOPKINS, supra note 25, at 578-79 for a description of the sparse legislative history of the 1934 legislation, which was also a floor amendment.

38 See Houck, supra note 25, at 16-23 (explaining how the National Economy League urged President Hoover to oppose increased government spending on veterans' benefits).

39 S. REP. NO. 73-558, at 26 (1934).

40 See H.R. REP. No. 73-1385, at 3-4 (1934) (Conf. Rep.) (showing the House and Senate agreeing to more limited language: "no substantial part of the activities of which is carrying on propaganda, or otherwise attempting, to influence legislation"). Representative Samuel B. Hill explained:

The Senate denied a deduction for contributions made to certain organizations, a substantial part of the activities of which was participation in partisan politics or carrying on propaganda or otherwise attempting to influence legislation. We were afraid this provision was too broad, and we succeeded in getting the Senate conferees to eliminate organizations, a substantial part of the activities of which was participation in partisan politics.

78 CONG. REC. 7729, 7831 (1934); see also Judith E. Kindell \& John Francis Reilly, Election Year Issues, in EXEMPT ORGANIZATIONS CONTINUING PROFESSIONAL EdUCATION TECHNICAL INSTRUCTION PROGRAM FOR FISCAL YEAR 2002, at 335, 336 (2001), available at http://www.irs.gov/pub/irs-tege/eotopici02.pdf ("The provision ... was deleted in conference, so that only the lobbying restriction remained."). 
later via the Johnson Amendment, in which Congress returned to the 1934 Senate language (except without an allowance for insubstantial political activity). ${ }^{41}$ The Johnson Amendment, to a certain extent, marked a continuation or culmination - at a glacial legislative paceof the discussion about politics and charity.

As chronicled by Professor Ann Murphy, Congress's enactment of the Johnson Amendment is best understood not by the relative absence of direct legislative history, but rather in the context of wider events, ${ }^{42}$ including the historical tension that had been ongoing in the Treasury, the courts, and the legislature since early in the century.

For example, prior to enactment of the Johnson Amendment, ${ }^{43}$ Congress had been holding extensive public hearings that investigated the political activities of charitable organizations. In 1952, the House of Representatives formed a special committee to investigate taxexempt foundations and other charities, ${ }^{44}$ known as the "Cox Committee." $"$ Specifically, the committee was charged with determining:

which ... foundations ... are using their resources for purposes other than the purposes for which they were established, and especially to determine which ... foundations ... are using their resources for un-American and subversive activities or for purposes not in the interest or tradition of the United States. ${ }^{46}$

Then, a new committee (the "Reece Committee") was formed to continue the work of the Cox Committee. ${ }^{47}$ The Reece Committee was charged with essentially the same task as the Cox Committee. It was to:

41 There is evidence that Johnson's staff was aware of the history of the 1934 amendment. O'Daniel, supra note 25, at 764-65. The history was described in the statement by the IRS before the Reece Committee, which appeared in Johnson's files with handwritten transcriptions, "presumably made by a Johnson staffer." Id. at 765.

42 Ann M. Murphy, Campaign Signs and the Collection Plate-Never the Twain Shall Meet?, 1 PITTSBURGH TAX REV. 35, 53 (2003) (footnote omitted) (“[W]hen Senator Johnson proposed his amendment . . . it is not surprising that it was adopted verbatim without hearings or testimony. Both sides of the political fence were disturbed by the potential of non-profit groups to wield political power.").

43 Johnson first became involved in the issue because of a letter he received on May 27, 1954, and proposed his Amendment on the Senate floor on July 2, 1954. O'Daniel, supra note 25 , at $760-65$.

44 H.R. Res. 561, 82d Cong., 98 Cong. Rec. 3489 (1952) (enacted).

45 H.R. REP. NO. 83-2681, at 1 (1954).

46 H.R. Res. 561, 82d Cong., 98 Cong. Rec. 3489 (1952) (enacted).

47 H.R. REP. NO. 83-2681, at 1 (1954). 
conduct a full and complete investigation and study of educational and philanthropic foundations and other comparable organizations which are exempt from Federal income taxation to determine if any foundations and organizations are using their resources for purposes other than the purposes for which they were established, and especially to determine which such foundations and organizations are using their resources for un-American and subversive activities; for political purposes; propaganda, or attempts to influence legislation. ${ }^{48}$

The Reece Committee held sixteen hearings, ${ }^{49}$ the last of which occurred the day Senator Johnson first proposed his political activities amendment. ${ }^{50}$ In its final written report, the Reece Committee concluded that:

It is the opinion of this Committee that the wording of the tax law regarding the prohibition of political activity should be carefully re-examined. We recognize that it is extremely difficult to draw the line between what should be permissible and what should not. Nevertheless, the present rule, as interpreted by the courts, permits far too much license. While further study may be indicated, we are inclined to support the suggestion that the limiting conditions of the present statute be dropped-those which restrict to the prohibition of political activity "to influence legislation" and those which condemn only if a "substantial" part of the foundation's funds are so used. These restrictions make the entire prohibition meaningless. We advocate the complete exclusion of political activity, leaving it to the courts to apply the maxim of de minimis no curat lex. Carefully devised exceptions to this general prohibition against political activity might be made in the case of certain special types of organizations, such as bar associations. ${ }^{51}$

The excerpt is revealing. It is a critique of the prevailing "prohibition on political activity," 52 which at the time ${ }^{53}$ included only the lobbying

48 Id. (emphasis added).

49 Id. at 2.

50 O'Daniel, supra note 25, at 765.

51 H.R. REP. NO. 83-2681, at 219 (first, second, and fifth instances of emphasis added).

52 Id.

53 The Committee's final report was released in December 1954, after passage of the Johnson Amendment, though apparently without taking it into account. Id. This could be ignorance of the new rule or it could be implicit support for it. It also could be that the report 
limit. In effect, the Reece Committee was saying that the then present rule did not go nearly far enough and urged changes to eliminate two loopholes. The first loophole was that the restriction covered only lobbying. Therefore, the Reece Committee said, the provision should be broadened in scope to cover all political activity, i.e., the language restricting the "prohibition" to activities "to influence legislation" should be "dropped." 54 The second loophole was that the law permitted insubstantial lobbying. This too the Reece Committee said should be changed, by eliminating the "substantial part" language. ${ }^{55}$ These two loopholes, the Reece Committee said, "make the entire prohibition meaningless." And so after months of hearings and agitation, the Reece Committee expressed the exact verdict reached by Senator Johnson, and, in turn, Congress: that politics and charity are incompatible.

So although the direct legislative record of the Political Activities Prohibition is sparse, the political and historical context that gave rise to enactment of the rule largely supports its adoption ${ }^{57}$ The two years prior to the Rule's enactment were notable for distrust of foundations and other charitable organizations and concern over their "political" involvement, broadly construed. Looking back to earlier in the century, the historical experience of charity and politics was characterized by suspicion and gradual retrenchment. Shortly after enactment of the income tax exemption and the charitable deduction, the Treasury Department and the courts both expressed doubt regarding the compatibility of charity and politics, and eventually, Congress followed suit. ${ }^{58}$ Rather than being an ad hoc overreaction to one man's political problem, the Rule is more fairly characterized as the product of debate occurring over decades (if not longer). ${ }^{59}$ Indeed,

was drafted mostly before enactment of the Rule but published afterward. In any case, there is little question but that the climate of the time was in favor of restrictions on the "political activity" of charitable organizations. See supra notes 41-45 and accompanying text (discussing the circumstances surrounding the Johnson Amendment).

54 H.R. REP. NO. 83-2681, at 219.

55 Id.

56 Id.

57 See supra note 42 (noting that the climate supported the Johnson Amendment).

58 See supra notes 33-37 and accompanying text (discussing the progression of attitudes).

59 Of course, there were and are questions about precisely what conduct was covered or intended to be covered by the legislative language of 1934 and of 1954. See Houck, supra note 25 , at 43 (noting a circuit court's failure to provide a citation supporting its elucidation of the purposes of the 1934 and 1954 amendments and asserting that "given the legislative history of the ... amendments, it would have been hard-pressed to do so"). But this does not obscure the central point that it is best to view the Johnson Amendment as a culmination of much that had preceded it. See supra note 42 and accompanying text (noting that the climate supported the Johnson Amendment). 
the ease of passage and subsequent lack of controversy regarding the Rule support the idea that by the time of its enactment it was a relatively uncontroversial proposition that charities should not be allowed to engage in political activity, broadly defined.

\section{B. Legislative Developments after Enactment}

The Political Activities Prohibition has been strengthened and reaffirmed by Congress over time. Congress revisited the subject of political activity and charity in 1969 and 1987, each time substantiating the thrust of the Rule. In the landmark Tax Reform Act of $1969,{ }^{60}$ Congress codified the distinction between public charity and private foundation, and subjected private foundations to a distinct anti-abuse regime. ${ }^{61}$ Included in the new rules was an excise tax on the political (and lobbying) activities of private foundations, which applied in addition to the loss of tax-exempt status. ${ }^{62}$ Also in 1969, Congress completed the work of the Johnson Amendment by codifying a 1958 Treasury regulation, ${ }^{63}$ which had provided that no charitable deduction is allowed for contributions to organizations that violate the Political Activities Prohibition of section 501(c)(3) ${ }^{64}$ It is significant both that the Department of Treasury, on its own authority, adopted this gap-filling rule in 1958, and that Congress reaffirmed it in the statute with little-to-no fanfare over a decade later. ${ }^{65}$

The 1987 legislation was the outcome of oversight hearings chaired by Congressman J.J. Pickle, Chairman of the House Ways and Means Subcommittee on Oversight. ${ }^{66}$ During the hearings, the Political Activities Prohibition was strongly supported by the Treasury, the current and a former IRS Commissioner, the American

60 Pub. L. No. 91-172, 83 Stat. 487.

61 See Staff of the Joint Comm. On TAXation, 91st Cong., General Explanation OF THE TAX REFORM ACT OF 1969, 29-62 (Joint Comm. Print 1970) (discussing the excise tax included in the Tax Reform Act of 1969).

62 See I.R.C. § 4945 (2006) (imposing 20 percent excise tax on amounts paid or incurred by private foundations "to carry on propaganda, or otherwise to attempt, to influence legislation ... [or] to influence the outcome of any specific public election, or to carry on, directly or indirectly, any voter registration drive").

63 Tax Reform Act of 1969, Pub. L. No. 91-172, 83 Stat. 487, 553 (codified as amended at I.R.C. $\$ 172$ ) ("the term 'charitable contribution' means a contribution or gift to or for the use of . . . a corporation, trust or community chest, fund, or foundation . . . no substantial part of the activities of which is carrying on propaganda, or otherwise attempting, to influence legislation, and which does not participate in, or intervene in (including the publishing or distributing of statements), any political campaign on behalf of any candidate for public office").

64 T.D. $6285,1958-1$ C.B. 127,130 (discussing the regulation that provided substantially similar language as the later Tax Reform Act of 1969).

65 There does not appear to be any legislative history that explains the change.

66 Lobbying and Political Activities of Tax-Exempt Organizations: Hearings Before the Subcomm. on Oversight of the H. Comm. on Ways and Means, 100th Cong. (1987). 
Bar Association and various other external stakeholders. ${ }^{67}$ The Rule was criticized by a number of organizations, ${ }^{68}$ but, despite the criticism, Congress strengthened the Rule by giving the IRS additional enforcement tools. ${ }^{69}$ First, Congress clarified that the Rule applied to actions "in opposition to" a candidate as well as "on behalf of" a candidate. ${ }^{70}$ Second, Congress provided that when an organization loses its status as a charitable organization, it could not subsequently seek tax exemption under section 501(c)(4) of the Code. ${ }^{71}$ Third, Congress imposed a new excise tax on expenditures in violation of the Rule. ${ }^{72}$ Finally, Congress enhanced the audit and enforcement procedures available to the IRS. ${ }^{73}$ Congress was clear that the Political Activities Prohibition should not be weakened. ${ }^{74}$

67 See id. at 88 (prepared statement of Roger Mentz, Assistant Secretary for Tax Policy of the Department of the Treasury) (stating that the political campaign activity prohibition was "sound tax policy" because there "is little to be said in favor of a general government subsidy of political campaigns" and that the Treasury "supports continuation of this prohibition"); $i d$. at 95-100 (prepared statement of Lawrence B. Gibbs, Jr., Comm'r of Internal Revenue) (indicating the IRS supported continuation of the restrictions); id. at 130 (statement of John B. Jones, Jr., Chairman of Taxation at the American Bar Association) (indicating that because political activities are easier to objectively define than lobbying activities, policy makers "can be more Draconian and take stronger positions" to curb political activities); id. at 222-36 (statement of former Comm'r of Internal Revenue Sheldon S. Cohen) (supporting the restrictions).

68 See id. at 247 (prepared statement of Edwin J. Feulner, Jr., President, The Heritage Foundation) (stating that "repeal of the lobbying rules .... would signal a new openness-a welcomeness if you will- to charities, to schools, to educational institutions, and to churches, to assume a rightful role in the legislative arena"); $i d$. at 426 (prepared statement of United States Catholic Conference) (arguing that " $[\mathrm{t}]$ he current broad IRS interpretation of the restriction has a substantial chilling effect on the role of churches and religious organizations in discussing not only particular candidates' views on issues of importance to members of the faith, but also in discussing the issues themselves").

69 The 1987 House Committee Report accompanying the legislation acknowledged that revocation of charitable status alone might not deter many organizations, "particularly if the organization cease[d] operations after it has diverted all its assets to improper purposes" and therefore an additional excise tax and audit procedures were warranted. H.R. REP. NO. 100-391, at 1624 (1987).

70 Omnibus Budget Reconciliation Act of 1987, Pub. L. No. 100-203, § 10711(a), 101 Stat. 1330-464 (codified in scattered sections of 26 U.S.C.).

${ }^{71} I d$. at $\$ 10711$ (b) (codified at I.R.C. $\$$ 504(a)(2)) (amending provision that organizations ceasing to qualify for exemption under I.R.C. $\$ 501(\mathrm{c})(3)$ for substantial lobbying are ineligible for section 501(c)(4) status to include organizations that lose qualification for substantial political activities). Section 501(c)(4) provides for federal income tax exemption for "social welfare" organizations, but contributions to such organizations are not deductible as charitable contributions. I.R.C. $\$ 504(c)(4)$.

72 Omnibus Budget Reconciliation Act $§ 10712$ (a) (codified at I.R.C. § 4955) (imposing a 10 percent excise tax on political expenditures by section 501(c)(3) organizations).

73 Id . at $\S 10713$ (a) (codified at I.R.C. § 7409) (authorizing civil action on behalf of the United States to enjoin flagrant violations); id. at $\S 10713$ (b) (codified at I.R.C. $\S$ 6852) (authorizing immediate assessments for flagrant violations).

74 See id. at 1624 ("The adoption of the excise tax sanction does not modify the presentlaw rule that an organization does not qualify for tax-exempt status as a charitable organization, and is not eligible to receive tax-deductible contributions, unless the organization does not participate in, or intervene in, any political campaign on behalf of or in opposition to any 
In short, since 1954, apart from some modest legislative enhancements, Congress has, with full knowledge of this fundamental principle of charitable tax law, left the Political Activities Prohibition alone.

\section{Criticisms of and Reasons for the Rule}

Over time, there have been attacks on the Political Activities Prohibition. Criticism comes essentially in three forms, relating either to mission, guidance, or enforcement.

Regarding mission, some charitable organizations, especially some churches, may see it as their mission to speak about issues of the day. Although the Rule allows charities to speak on issues, ${ }^{75}$ such organizations believe that the Rule compromises their mission by denying the organization the ability to connect passion on the issues to the voting booth. ${ }^{76}$ There has been considerable scholarship addressing whether the Rule should be relaxed for such organizations, and whether the Rule could withstand a constitutional challenge under the First Amendment's Free Exercise Clause. ${ }^{77}$ To the extent there

candidate for public office.").

75 See I.R.S., Tax Guide for Churches and Religious Organizations, Pub. No. 1828, at 6 (2009), available at http://www.irs.gov/pub/irs-pdf/p1828.pdf ("Churches and religious organizations may, however, involve themselves in issues of public policy without the activity being considered as lobbying. For example, churches may conduct educational meetings, prepare and distribute educational materials, or otherwise consider public policy issues in an educational manner without jeopardizing their tax-exempt status.").

76 See, e.g., CRIMM \& WINER, supra note 27, at 7 (noting spiritual leaders may "feel theologically compelled to engage in political campaign speech"); Lloyd Hitoshi Mayer, Politics at the Pulpit: Tax Benefits, Substantial Burdens, and Institutional Free Exercise, 89 B.U. L. REv. 1137, 1168-69 (2009) (footnote omitted) (noting that "[m]any religious faiths, perhaps all, view the transmission of a holistic worldview that impacts all aspects of their adherents' lives as an integral part of their mission. Therefore it would not be surprising to find that some houses of worship believe instructing their congregations with respect to political involvement to be as important to their religious teaching as instructing them on personal relationships or finances."); see also Review of Internal Revenue Code Section 501(c)(3) Requirements for Religious Organizations: Hearing Before the Subcomm. on Oversight of the Comm. on Ways and Means, 107th Cong. 56 (2002) (statement of D. James Kennedy, Coral Ridge Ministries President) (noting that "[e]ven addressing moral concerns, such as abortion, from the pulpit during an election campaign may violate the IRS rule if abortion, for example, is under debate in the campaign. With so much uncertainty and so much at risk, silence is, regrettably, the only option for the minister who wants to ensure that the IRS does not open a file on his church.").

77 See generally CRIMM \& WINER, supra note 27 (providing a thorough and penetrating analysis of the First Amendment issues raised by the Rule with respect to houses of worship); see also Mayer, supra note 76, at $1140 \mathrm{n} .14$ (collecting articles); id. at 1215 (arguing that as currently applied to "sermon[s] delivered during a house of worship's regular service," the prohibition would survive a Free Exercise challenge, but that such a challenge would be successful under the higher standard imposed by the Religious Freedom Restoration Act). 
have been serious recent legislative challenges to the Rule, they have occurred due to mission concerns. ${ }^{78}$

Mission concerns go straight to the heart of the Rule. Other concerns are less direct. One of the most common complaints is that the Rule is imprecise. For charities that want to engage in activity that may be close to the political activity line, the absence of a bright line, and what is asserted to be insufficient guidance, provokes dissent. ${ }^{79}$ Notwithstanding such complaints, there is a canon of guidance published by the IRS explaining the parameters of the Rule, ${ }^{80}$ and some courts have also weighed in ${ }^{81}$ Criticism about lack of guidance is to a certain extent criticism of the lack of a bright line, or way of knowing in advance whether a contemplated activity is prohibited. Thus, the objection is partly directed to the overall facts and circumstances approach to the prohibition and the resulting lack of "yes or no" answers to questions about political activity. ${ }^{82}$ Accordingly, some have suggested that the IRS should adopt a series of safe harbors. ${ }^{83}$ Others have urged that political activity be treated

78 Since 1987, a number of bills have been introduced in Congress to relax the Rule, but none has made it out of Committee. See Lloyd Hitoshi Mayer, Grasping Smoke: Enforcing the Ban on Political Activity by Charities, 6 FIRST AMEND. L. REV. 1, 4 n.8 (2007) (listing bills from the 107th through the 110th Congresses). The House Committee on Ways and Means took up legislation on the subject in 2004, but it proved controversial and was eventually dropped. H.R. 4520, 108th Cong. $§ 692$ (2004). The safe harbor provision, inserted as part of a much larger tax bill, the American Jobs Creation Act of 2004, would have allowed churches to keep charitable tax status for up to three violations of the prohibition, but the church would be subjected to tax based on its gross income, with the rate of tax increasing for each violation. Id. In the interest of disclosure, the author, at the time Counsel to the Congressional Joint Committee on Taxation for tax-exempt organization matters, helped to draft the legislation.

79 See, e.g., Kay Guinane, Wanted: A Bright-Line Test Defining Prohibited Intervention in Elections by 501(c)(3) Organizations, 6 FIRST AMEND. L. REV. 142, 143 (2007) (arguing that the current standard is too vague).

80 See Rev. Rul. 2007-41, 2007-1 C.B. 1421 (providing twenty-one examples of permitted and prohibited voter education activities, voter registration, candidate appearances, issue advocacy, rental of facilities, provision of mailing lists, use of websites and other activities); Rev. Rul. 86-95, 1986-2 C.B. 73 (allowing a series of public forums if the forum and content are neutral); Rev. Rul. 80-282, 1980-2 C.B. 178 (addressing factors that show bias in the timing and distribution of voter guides); Rev. Rul. 78-248, 1978-1 C.B. 154 (providing guidance on the permitted content and structure of candidate questionnaires); Rev. Rul. 74-574, 1974-2 C.B. 161 (allowing sponsoring of candidate debates and forums that are educational and impartial); Rev. Rul. 67-71, 1967-1 C.B. 125 (providing that the evaluation of the qualifications of candidates or support for a slate of candidates violates the prohibition); Rev. Rul. 66-256, 1966-2 C.B. 210 (allowing sponsoring of candidate debates and forums that are educational and impartial).

81 See, e.g., Ass'n of the Bar of N.Y. v. Comm'r, 858 F.2d 876, 881-82 (2d Cir. 1988) (finding that the rating of judicial candidates on a nonpartisan basis violated the Rule).

82 See Donald B. Tobin, Political Campaigning by Churches and Charities: Hazardous for 501(c)(3)s, Dangerous for Democracy, 95 GEO. L.J. 1313, 1350 (2007) ("The facts and circumstances approach has been widely criticized and poses significant problems for 501(c)(3) organizations.").

83 See Letter from Ellen Aprill, Professor at Loyola Law Sch., to the Comm'r of The Internal Revenue Serv. et al. (Nov. 29, 2005), reprinted in Loyola Professor Suggests IRS Issue 
similar to lobbying. ${ }^{84}$ Relatedly, IRS enforcement of the Rule generates controversy through allegations of uneven enforcement ${ }^{85}$ or political bias. ${ }^{86}$

Although such criticisms of the Rule are important, they should be put into the context of the charitable sector as a whole by considering which types of section 501(c)(3) organizations are most directly affected by the Rule. Generally, these are the organizations that either are compelled by their mission (or believe they are so compelled) to participate in politics, or advocacy-oriented organizations. The first type is somewhat exceptional, legally and practically. ${ }^{87}$ The second type, however, is the Rule's precise target. Advocacy organizations, by their very nature, live on the line between campaign intervention and advocacy, between lobbying and education. It harkens back to the Reece Committee's acknowledgement "that it is extremely difficult to draw the line between what should be permissible and what should not," ${ }^{, 88}$ and so it has proved. But that there is activity around the line should come as no surprise. More important is that the frustration comes from just one segment of the charitable sector, which is just that, a segment. Notable is the relative quiescence with which the rest of the charitable sector, and the public, have accepted the Rule. ${ }^{89}$

Guidance on Charities and Political Activity, TAX NOTES TODAY, Dec. 2, 2005, available at LEXIS, 2005 TNT 231-18 (providing letter urging guidance); Loyola Professor Proposes Safe Harbors for Political Campaign Activity by 501(c)(3) Groups, TAX NOTES TODAY, Dec. 2, 2005, available at LEXIS, 2005 TNT 231-19 (providing enclosure to Professor Aprill's letter listing four specific safe harbors); Mayer, supra note 78, at 25 (arguing that the IRS should "create bright lines and safe harbors wherever possible").

84 See Johnny Rex Buckles, Is the Ban on Participation in Political Campaigns by Charities Essential to Their Vitality and Democracy? A Reply to Professor Tobin, 42 U. RICH. L. REV. 1057, 1077 (2008) (arguing that "federal tax law could permit charitable entities to engage in electioneering to the same degree that they may engage in lobbying - as an insubstantial part of their total activity").

85 See Mayer, supra note 78, at 7-13 (summarizing the IRS's recent enforcement efforts); Tobin, supra note 82, at 1354 ("The current enforcement regime creates uncertainty and has the potential for political manipulation.").

86 See StafF OF the J. COMM. On TAXATION, 106Th CONG., ReP. OF InVESTIGATION OF Allegations Relating to Internal Revenue SERvice Handling of TAX-EXempt Organization MatTers 19 (Comm. Print 2000) (nothing that "[w]hile the Joint Committee staff found no credible evidence of political bias in the IRS's selection of tax-exempt organizations ... [it] did identify certain procedural and substantive problems . . that may have contributed to a perception of unfairness"); Mayer, supra note 78, at 4-5 (discussing allegations of partisan bias).

87 To examine the claims of religious organizations is beyond the scope of this Article, but there is considerable scholarship on the issue. See, e.g., CRIMM \& WINER, supra note 27, at 280-81, 315-16 (noting that legal authorities generally pertinent to analysis of the constitutionality of the Rule may not fully control in the context of houses of worship).

88 H.R. Rep. No. 83-2681, at 219 (1954).

89 Broadly speaking, the Rule is largely accepted by charitable organizations and the public. See Chisolm, supra note 30, at 314 (noting that "the prohibition has received little 
This is because there are good reasons for the Rule, which explain not only its enactment, but its staying power. Although there is, without question, no unequivocal statement as to what Congress intended in 1913, 1917, 1934, or 1954 when it enacted the provisions for the tax-exempt status for charities, the deductibility of charitable contributions, the lobbying rule, or the Political Activities Prohibition, the restrictions on political and lobbying activity were no accident. The prevailing concern was definitional, that such activities were generally inconsistent with charity, as defined by Congress. Consider the following statements by Congress, the Treasury Department, and the courts:

(1) The Treasury in 1919: "[A]ssociations formed to disseminate controversial or partisan propaganda are not educational within the meaning of the statute." 90

(2) The Treasury in 1920: "It is a matter of common knowledge that propaganda in the popular sense is disseminated not primarily to benefit the individual at whom it is directed, but to accomplish the purpose or purposes of the person instigating it."

(3) Circuit Judge, Learned Hand in 1930: "Political agitation as such is outside the statute, however innocent the aim .... Controversies of that sort must be conducted without public subvention: the Treasury stands aside from them." ${ }^{92}$

(4) Congress in 1954: "The foundations are free to do as they please with the public funds at their command, so long as they do not transgress certain rules of law .... Political propaganda, for example is proscribed." 93

attention"). There is no sense that charities find the Rule to be especially constraining: hospitals are more concerned with other aspects of charity law to be worrying about engaging in partisan activity. Colleges and universities have not argued that they should be allowed to engage in politics. Nor have social service organizations, cultural organizations, or even private foundations thought to place modifying or repealing the Rule on the agenda. (Lobbying of course is a different matter.) Id. (noting the extensive literature criticizing the lobbying restrictions). Support for change to the Rule also does not appear forthcoming from the public at large.

90 T.D. 2831,21 Treas. Dec. Int. Rev. 170, 285 (1919).

91 S. 1362 , 2 C.B. 152,154 (1920).

92 Slee v. Comm'r, 42 F.2d 184, 185 (2d Cir. 1930).

${ }^{93}$ H.R. Rep. No. 83-2681, at 22. 
(5) Congress in 1954: "[W]hen a proposed activity may have political implications, we cannot see any reason why public funds should be used when any political impact may result." 94

Although these statements do not amount to any single rationale for the Rule, ${ }^{95}$ nevertheless, Congress uses the Rule to define charity for tax purposes. In doing so, it expresses a number of important and related policies, all of which serve the fundamental judgment that a political purpose is not a charitable purpose, and that political activity may not serve a charitable purpose.

For instance, because of the Rule, a charitable section 501(c)(3) organization must focus on charitable not political purposes and must be free of partisanship. If education is the purpose of an organization, activities must be educational, and not veer into propaganda. ${ }^{96}$ The Rule is also an important defense mechanism because it protects charities from political capture and the serving of private interests.

94 Id. at 219. The report reiterated this rationale for a Political Activities Prohibition, stating that political activity by charitable organizations amounted to a "mis-use of public trust funds." Id. at 18 .

95 In recent years, consensus appears to have emerged that, in general, there are three lines of justification for the Rule with varying degrees of resonance. First is the idea that the federal government should remain neutral in political affairs, or the "nonsubvention principle." The principle's pedigree is Judge Learned Hand's statement in Slee that "[c]ontroversies of that sort [i.e., political agitation] must be conducted without public subvention; the Treasury stands aside from them." 42 F.2d at 185. Second, the Rule has been justified as a means of supporting the private benefit doctrine: namely, political activity is viewed as an activity for private gain and not for public benefit, and therefore should not be subsidized. Chisolm, supra note 30, at 35859. Third, charity, by definition, just does not include political activity (including lobbying). See, e.g., Johnny Rex Buckles, Not Even a Peep? The Regulation of Political Campaign Activity by Charities Through Federal Tax Law, 75 U. CIN. L. REV. 1071, 1090-92 (2007) (summarizing and responding to the argument that electioneering by charitable entities should be forbidden because political activities are not charitable); Chisolm, supra note 30, at 359-62 (same).

Each of those rationales has been criticized, as, in general, insufficient to support the Rule. Buckles, supra note 95, at 1078-92 (addressing the three justifications for the Rule and arguing they are not sufficient to prohibit all charitable entities from engaging in political activities). The neutrality rationale is perhaps the easiest to criticize. Neutrality can be maintained equally effectively with a prohibition or its opposite - unlimited political activity for all charities. In either case, government remains "neutral." Regardless, each of the three rationales seems to be a variation on the definitional theme, with neutrality and preventing private benefit being derivative theories. As Judge Hand said, if "[p]olitical agitation as such is outside the statute," then it follows that "the Treasury stands aside from them," i.e., does not subsidize. Slee, 42 F.2d at 185 . In other words, the neutrality rationale is little more than another way to assert that charity is defined not to include political activity; i.e., public funds are not to be used or spent on political activity. It follows quite naturally that what is not charity will not be supported by the charitable tax benefits; the Treasury will "stand aside" from noncharitable activity and not "provide a subsidy" for it. Similarly, the no-private-benefit rationale is yet another way to say the same or a like thing. The no-private-benefit rule itself is derived from the charitable purpose requirement as an organization cannot primarily be charitable if it is operated primarily for private interests.

96 T.D. 2831, 21 Treas. Dec. Int. Rev. 170, 285 (1919) (“[A]ssociations formed to disseminate controversial or partisan propaganda are not educational within the meaning of the statute."). 
Political activity, partisanship, bias, and non-neutrality often are equated and generally regarded as serving private interests. ${ }^{97}$ By barring all political activity, the Rule removes any discretion otherwise left to the IRS to determine when private benefit exists. Thus, the Rule is a prophylactic measure; i.e., Congress felt comfortable enough to say flat out that certain activity is not permitted.

In addition, and perhaps most critically, the Rule provides an outer boundary to the scope of the charitable sector, despite the difficulties of enforcement. Policing the border of the charitable exemption, ${ }^{98}$ the Rule is one of the few bright-lines ${ }^{99}$ that places a meaningful limit on the charitable purpose requirement and so constrains the scope of the charitable tax benefits. ${ }^{100}$ As discussed in Part IV of this Article, alternatives to the Rule would mean loss of this border control function, and so are not appealing, conceptually or administratively. They would also likely lead to a significant loss of revenue.

In short, fundamentally, the decision about what is and is not charitable, given a baseline of taxable status and nondeductibility of contributions to organizations, ${ }^{101}$ is a revenue decision by Congress. It is not a metaphysical question about the true meaning of charity, apart from what Congress (or the courts) thinks it means. Those who disagree with the policy may dissent, but the decision is considered policy nonetheless. In providing tax benefits, Congress had some idea about what constituted a charitable purpose or a charitable activity ${ }^{102}$ - the details were left to events. And events confirmed and reaffirmed the initial instinct that charity and political activity, for purposes of the tax law, were mutually exclusive.

97 See Chisolm, supra note 30, at 337 ("[A]llowing political involvement invites misuse of the section 501(c)(3) form in pursuit of private interests, rather than for the broad public benefit that the charitable classification is designed to promote.").

98 See, e.g., Simon, Dale \& Chisolm, supra note 27, at 284-85 (explaining that the Political Activities Prohibition serves a "border control" function, namely, keeping the public affairs and charitable spheres separate).

99 The others are the lobbying limitation and the taxation of unrelated business income. I.R.C. $\S \S 501(\mathrm{c})(3), 511-514(2006)$.

${ }^{100}$ Rules that provide some constraint to the scope of the charitable tax benefits are important especially in light of the recent growth of the charitable sector, the relatively openended nature of charitable tax status, and the relative lack of enforcement or enforceable rules. For a discussion, see Roger Colinvaux, Charity in the 21st Century: Trending Toward Decay, 11 Fla. TAX REV. 1 (2011).

${ }^{101}$ But see CRIMM \& WINER, supra note 27, at 285 (stating that for houses of worship "[h]istorically ... the tax exemption is the baseline; [the exemption] was in place for many decades before the Johnson Amendment added the restraint on political campaign speech").

${ }^{102}$ See Chisolm, supra note 30, at 346 (discussing Congress's attempts to define "charitable purposes"). 
Of course, just because Congress has answered the question, it does not follow that the policy should continue in perpetuity. ${ }^{103} \mathrm{In}$ theory, the idea of charitable organizations taking sides in politics is attractive. Under a free market of ideas approach to speech, the truth, or information, will be better served with more speech. The public will have new perspectives to consider that may be more informative, educational, and detached than many of the political voices shrieking the loudest today.

Further, allowing political activity by charities is not a mandate; charities may remain agnostic and apart from the political process. To the extent that the consumers of charity do not want charities to become involved in politics, many, if not most, charities will respond to this sentiment and remain aloof. It is easy to imagine a charity, dipping a toe in the political water to endorse a candidate for the first time, only to hear from angry donors and others that the activity was inappropriate. A charity's stakeholders might also accuse the charity of endorsing the wrong candidate, or argue that the charity should not even risk endorsing a losing candidate, for fear of jeopardizing the charity's standing in the community as an opponent of an elected official. Just as with for-profit corporations, ${ }^{104}$ the risk that a charity's direct political activity could harm its relationships with its supporters is likely to be high, and constraining. ${ }^{105}$ Moreover, in a sector of over 1.5 million organizations, ${ }^{106}$ not including churches, ${ }^{107}$ the percentage

${ }^{103}$ Debate about the proper relationship between politics and charity is an ongoing one. In a recent spirited defense of the Rule, Professor Donald Tobin argued that the Rule protects the independence of section 501(c)(3) organizations, that campaign intervention generally is inconsistent with an educational or charitable mission, and that campaigning by section 501(c)(3) organizations would harm the democratic process. Tobin, supra note 82, at 1319-20. By contrast, others believe that free speech and organizational mission would be better served if charities had a political voice. See, e.g., Buckles, supra note 84, at 1062 (responding to Tobin's argument). The debate is an earnest one, and perhaps may fairly be characterized as a policy struggle between those concerned about the consequences of a partisan and "not so independent" sector and those embracing a braver world of new political voices informing the public debate.

${ }^{104}$ See Jia Lynn Yang \& Dan Eggen, Campaign Spending Puts Target in Bulls-Eye, WASH. PosT, Aug. 19, 2010, at A1 (discussing the repercussions of Target's decision to donate money to a pro-business group).

105 See, e.g., Frances R. Hill, Corporate Philanthropy and Campaign Finance: Exempt Organizations as Corporate-Candidate Conduits, 41 N.Y.L. SCH. L. REV. 881, 941 (1997) ("To the extent that particular exempt organizations take positions on particular electoral contests, they may gain the advantage of intensifying the support of some members and even of attracting some new members, but they also risk alienating current and potential members and supporters. For exempt organizations with their own agendas of exempt activity, these risks should be taken seriously.").

106 Molly F. Sherlock \& Jane G. Gravelle, Cong. Research Serv., R40919, AN OVERVIEW OF THE NONPROFIT AND CHARITABLE SECTOR 3 (2009). This figure does not include organizations that do not file an exemption application with the IRS, which could number in the hundreds of thousands (e.g., churches, other qualifying religious organizations, and very small organizations). Id. Approximately 116,000 of the 1.5 million organizations are private 
of those likely to do much more than endorse a candidate is likely to be small - politics is not really a natural fit for many charities.

So, for the most part, ${ }^{108}$ a relaxation of the Political Activities Prohibition should not dramatically change the makeup of the activities of existing organizations. Charities that already advocate on issues, a small percentage of the total, are expected to do so by their supporters and will have more tools to advance their mission. More traditional charities-hospitals, colleges and universities, social service organizations, and arts organizations - might abstain from a new found freedom to engage in politics. Churches may be unique. Some would likely endorse candidates and take more active electoral steps. Others would not. Some might regret a foray into politics. Others might relish it. But the ultimate success or failure of the project would likely be decided by the parishioners - who can vote with their feet.

Taking the above thoughts into account, the Rule and its defenders may come across as paternalistic and overly concerned about what might happen. The parade of horribles offered - the loss of independence, the diversion from, and perhaps compromise of, mission, in effect the corruption of the sector-would be a terrible outcome. Need it be feared? There should be little dispute that the admirable and aspirational qualities of charitable organizations are, to a certain extent, noble ones; a nobility that rises above faction. The sphere of political campaigns, by contrast, is characterized by fighting, deceit, and dirty maneuvers - all perhaps in the service of a public good - but hardly noble qualities. Being in service to ideas, helping others, advancing culture, and delivering a needed good are the core expectations that we have of charity. While permitting involvement in political activities may not necessarily lead to the corruption of the charitable sector, it would introduce an ignoble quality to the sector from which the Rule has provided a shield. And, as discussed in Part IV, it would seriously dilute an already fluid concept of charity.

Ultimately, whether the Rule should be changed is a question that should be decided not from fear about what might happen, but rather by reconsidering the questions Congress already answered in enacting the Rule: Is political activity charitable? Should it be? It is noteworthy

foundations. $I d$.

${ }^{107}$ See id. at 3 ("Churches and other qualifying religious organizations are exempt from the annual information-reporting requirements.”).

${ }^{108}$ As argued in Part IV, however, change to the Rule likely would bring many new entrants. 
that we live in a time where distrust of government is high. The public's distrust of government could be a product of the intense partisanship and preeminence of selfish motives that is part of the political process. Distrust of many of our institutions, public or private, for-profit or not-for-profit, is also high. Such distrust, many would argue, is not warranted. But to the extent that the Rule protects an important part of our society from further distrust, it is a good thing.

\section{Does Citizens UNITED Condemn the PolitiCAL ACTIVITIES PROHIBITION?}

\section{A. Introduction}

The reason to question anew the Political Activities Prohibition stems from the Supreme Court's recent decision Citizens United $v$. Federal Election Commission. ${ }^{109}$ The case concerned a nonprofit corporation, Citizens United, organized under section 501(c)(4) of the Code. ${ }^{110}$ In January 2008, Citizens United released a film called "Hillary: The Movie," which was very critical of Hillary Clinton, who was at the time a senator and a candidate for the presidency. ${ }^{111}$ The Court concluded that "there is no reasonable interpretation of Hillary other than as an appeal to vote against Senator Clinton" and that "the film qualifies as the functional equivalent of express advocacy."112 Accordingly, the Court said, section $441 \mathrm{~b}$ of the Federal Election Campaign Act ("FECA"), ${ }^{113}$ as amended, prevented Citizens United from releasing the film. ${ }^{114}$ The Court held, however, that the part of

109130 S. Ct. 876 (2010).

${ }^{110}$ Id. at 936 (Stevens, J., dissenting). According to the Court, Citizens United had an annual budget of about $\$ 12$ million, and received most of its funds from individuals but also received some contributions from for-profit corporations. $I d$. at 887 . Because of the corporate contributions, Citizens United could not qualify for the exception to the rule created in Federal Election Commission v. Massachusetts Citizens for Life, Inc., 479 U.S. 238, 263-64 (1986), that restrictions on corporate expenditures in political campaigns were unconstitutional as applied to nonprofit corporations "that were formed for the sole purpose of promoting political ideas, did not engage in business activities, and did not accept contributions from for-profit corporations or labor unions." Citizens United, 130 S. Ct. at 891. Section 501(c)(4) of the Code describes "social welfare" organizations. I.R.C. § 501(c)(4) (2006). It differs from section 501(c)(3) of the Code in several important respects. See infra Part II.B.1 (explaining the distinctions between section 501(c)(3) and section 501(c)(4) organizations).

$111130 \mathrm{~S}$. Ct. at 887.

112 Id. at 890 . (2006)).

${ }^{113}$ Pub. L. No. 92-225, 86 Stat. 3 (1972) (codified as amended at 2 U.S.C. § 441b(a)

$114130 \mathrm{~S}$. Ct. at 891 . Section $441 \mathrm{~b}$ (a) provides in part that: "It is unlawful for . . any corporation ... to make a contribution or expenditure in connection with any election to any political office ..." 2 U.S.C. $\S 441 b(a)$ (2006). Section $441 b(b)(2)$ provides that the term 
section $441 \mathrm{~b}$ that bars corporations from making independent expenditures and electioneering communications (the "Electioneering Rule") was an unconstitutional burden on Citizens United's right to free speech under the First Amendment, and, therefore Citizens United had a right to release the film. ${ }^{115}$ In reaching this conclusion, the Court overruled a prior decision, Austin v. Michigan Chamber of Commerce $^{116}$ in its entirety, and part of McConnell v. Federal Election Commission. ${ }^{117}$

Assume that subsequently, in 2012, a corporation called "Our Country," recognized as a charity under section 501(c)(3) of the Code, releases a film called Obama: The Movie. This movie is, in many respects, a sequel to Hillary but with a different star and bears no reasonable interpretation other than as an appeal to vote against President Obama in his campaign for re-election. The IRS investigates the organization, concludes there has been a violation of the Political Activities Prohibition, and revokes Our Country's taxexempt status. Our Country appeals, the case reaches the Supreme Court, and the Court must rule on the constitutionality of the Political Activities Prohibition. The Court will either distinguish or follow Citizens United, making careful analysis of the Court's opinion in Citizens United critical to understanding the continuing validity of the Political Activities Prohibition.

The key threshold issue for the Court in Citizens United was whether the Electioneering Rule was a burden on speech. ${ }^{118}$ The Court answered in the affirmative. ${ }^{119}$ Strict scrutiny of the

“'contribution or expenditure' includes a contribution or expenditure ... for any applicable electioneering communication.” 2 U.S.C. § $441 b(b)(2)$.

${ }^{115}$ Citizens United, 130 S. Ct. at 917.

116494 U.S. 652 (1990), overruled by Citizens United, 130. S. Ct. at 913.

117540 U.S. 93 (2003), overruled in part by Citizens United, 130 S. Ct. at 913.

118130 S. Ct. at 892. In general, understanding the structure of the Court's majority opinion is useful. The opinion is divided into five parts. Part I provides the factual and procedural background. Id. at 886-88. Part II explains why the Court undertook a facial challenge to the statute (instead of an as-applied challenge), and why the Court believed that it had to decide the constitutional issue directly, i.e., without resorting to circumlocutions of statutory interpretation. Id. at 888-96. Part III is organized into introductory material, $i d$. at 89699, and then four sections, A, B, C, and D. In Part III.A, the Court explained its conclusion that there are conflicting lines of precedent regarding the constitutionality of the Electioneering Rule, thus warranting its decision. Id. at 899-903. Part III.B analyzed the three proffered government interests in the Electioneering Rule - the anti-distortion rationale, corruption and the appearance of corruption, and shareholder protection - concluding that none is a compelling state interest. $I d$. at 903-11. Part III.C discussed the relevance of stare decisis to the Court's decision. Id. at 911-13. Part III.D explicitly overruled Austin, as well as a portion of McConnell. $I d$. at 913. Part IV related to the disclosure provisions. Id. at 913-16. In Part V, the Court concluded. Id. at 916-17.

${ }^{119} I d$. at 917. 
Electioneering Rule followed, requiring a compelling state interest in support of it, which was held not to exist. ${ }^{120}$ Importantly, in concluding that the Electioneering Rule was a burden on speech, the Court considered four factors: (1) the purpose of the Electioneering Rule to suppress speech; (2) the criminal sanction for violating the Electioneering Rule; (3) the nature of the rule as a ban on speech; and (4) the Electioneering Rule's identification of certain preferred speakers. ${ }^{121}$ As discussed below, however, with respect to each of these factors - purpose, sanction, and a ban on corporate speech - the Political Activities Prohibition is distinguishable from the Electioneering Rule and Citizens United. Accordingly, the Court is not compelled to follow the reasoning of Citizens United in considering the Political Activities Prohibition, which, as argued infra, is not a burden on speech in the same sense as the Electioneering Rule. Therefore, the Political Activities Prohibition should be subject to a lesser standard of review (and thus probably survive scrutiny).

\section{B. Purpose of the Rule}

\section{Purpose of Section 501(c)(3) is to Define Charity for Tax Purposes}

There is little room to doubt that the Electioneering Rule of section $441 \mathrm{~b}$, including the now unconstitutional ban on corporate independent expenditures, is a rule "to control or suppress speech."122 The ban on corporate contributions to political candidates and campaigns and the ban on corporate independent expenditures are overt Congressional efforts to regulate speech in the electoral process. Indeed, the entire apparatus of campaign finance laws and regulations are intended to regulate core First Amendment speech. Accordingly, Part III of the Court's opinion in Citizens United began by quoting the First Amendment to the U.S. Constitution: "Congress shall make no law ... abridging the freedom of speech." ${ }^{.23}$ Then, the Court said that "[1]aws enacted to control or suppress speech may operate at different points in the speech process." ${ }^{124}$ Implicit in this statement is the

${ }^{120} \mathrm{Id}$. at $903-11$.

${ }^{121} \mathrm{Id}$. at 896-99. The implications of Citizens United for the Political Activities Prohibition lie mostly in the introductory material to Part III of the Court's opinion, in which the Court provided the decision's framework, equally applicable to Our Country in the hypothetical posed above as to Citizens United. See also Galston, supra note 12, at 890-902 (describing the scrutiny through which the court reviews campaign finance laws).

122 Citizens United, 130 S. Ct. at 896.

${ }^{123}$ Id. (quoting U.S. CONST. amend. I).

${ }^{124} I d$. 
Court's articulation of the purpose of the Electioneering Rule: to control or suppress speech. The Court later reiterated that the Electioneering Rule's "purpose and effect" is "to silence entities whose voices the Government deems to be suspect." 125

By contrast, section 501(c)(3) of the Code has a different purpose. Notwithstanding that the rationale for section 501(c)(3) has been debated amid an obscure legislative history, ${ }^{126}$ the section manifestly is not about the regulation of speech. It is not a law "enacted to control or suppress speech." ${ }^{127}$ Rather, it is a law enacted to describe a type of organization that is not subject to federal income tax.

Congress requires a section 501(c)(3) organization ${ }^{128}$ to meet four requirements: (1) it must be organized and operated for an exempt purpose; (2) no earnings of the organization may inure to the benefit of insiders; (3) there may be no substantial lobbying; and (4) no political activity is allowed. ${ }^{129}$ If all four requirements are met on an ongoing basis, then the organization is a "charity" for tax law purposes.

The statute's structure is important because it shows that the Political Activities Prohibition is definitional. Quite simply, an organization is not a charity under section 501(c)(3) if it engages in political activity. This matters because there is an ongoing fault-line between "charity" for tax law purposes and "charity" viewed more normatively and apart from the tax law. Often, commentators describe charity in the normative, aspirational sense and the Political Activities

${ }^{125} \mathrm{Id}$. at 898 .

${ }^{126}$ See Evelyn Brody, Of Sovereignty and Subsidy: Conceptualizing the Charitable Tax Exemption, 23 J. CORP. L. 585, 590 n.23 (1998) (explaining the several theories behind charitable exemptions but highlighting the lack of legislative expression regarding tax benefits for charities); Nina J. Crimm, An Explanation of the Federal Income Tax Exemption for Charitable Organizations: A Theory of Risk Compensation, 50 FLA. L. REV. 419, 430-39 (1998) (exploring several theories of charitable tax exemption).

${ }^{127}$ Citizens United, 130 S. Ct. at 896. The cases the Citizens United Court cited for examples of unconstitutional laws that suppress speech are all qualitatively different from section 501(c)(3). See id. at 896-97 (citing Watchtower Bible \& Tract Soc'y of N.Y., Inc. v. Village of Stratton, 536 U.S. 150, 165-66 (2002) (striking down a village ordinance regulating door-to-door canvassing on First Amendment grounds as applied to religious proselytizing, anonymous political speech, and the distribution of handbills); Simon \& Schuster, Inc. v. Members of N.Y. State Crime Victims Bd., 502 U.S. 105, 116 (1991) (finding a state financial regulation inconsistent with the First Amendment because it placed a content-based financial burden on speech); Brandenburg v. Ohio, 395 U.S. 444, 448 (1969) (per curiam) (finding that the Ohio Criminal Syndicalism Act violated the First Amendment because it failed to distinguish mere advocacy and abstract teaching from incitement to imminent lawless action); N.Y. Times Co. v. Sullivan, 376 U.S. 254, 264 (1964) (reversing judgment awarded in a civil libel action as inconsistent with First Amendment principles of freedom of speech and of the press because statements critical of public officials in their official conduct are protected)).

${ }^{128}$ A section 501(c)(3) organization can take the form of a corporation, community chest, fund, or foundation. I.R.C. $\$ 501(\mathrm{c})(3)$ (2006).

${ }^{129}$ I.R.C. § 501(c)(3) (2006). 
Prohibition as if it were external to charity, properly defined, viewing charity independently of the Rule. ${ }^{130}$ This is in many respects the principal tension underlying charitable exemption: organizations may view section 501(c)(3) status as an entitlement, and any conditions imposed for such status as anathema.

For example, Professor Chisolm described the Political Activities Prohibition as "an unavoidable choice: either exercise its right to free political expression and forfeit the benefit of tax exemption to which its charitable character otherwise entitles it, or claim its entitlement and forgo the right." ${ }^{\prime 131}$ But note that, because the Political Activities Prohibition is definitional, an organization that engages in political activity does not have a "charitable character," at least not under the tax law. This illustrates the normative versus the tax law definition of charity. Professor Chisolm argued more from the normative sidewhether charity should be defined as exclusive of political activity for tax law purposes. Thus, in her analysis of the Rule's rationale, she said that the reason for the Rule could have stemmed from "definitional consistency." 132 That is, Congress decided that the tax law definition of charity should conform to its understanding of a common law definition. Nevertheless, although definitional consistency may explain Congress's decision, the point is that Congress did not have to define charity as it did, or in accord with any common law or other norm. What matters is that Congress did decide to define charity to include the Political Activities Prohibition, and not whether charity in a normative sense should include such a rule.

Further, the purpose of the definition was not to suppress speech. As discussed above, there are many reasons supporting a prohibition on political activities as part of the definition of a tax-exempt charity: (1) Congress wants charities to focus on core charitable activity; (2) Congress wants a charitable sector untainted by partisan flavor; (3) Congress does not want to subsidize political activity through exemption; (4) Congress wants to protect charities from political capture; and (5) Congress does not think political activity is charitable activity. ${ }^{133}$ In short, Congress decided to define charity to exclude political activity (and private inurement, and substantial lobbying). In so doing, Congress was trying to promote something, charity, by

${ }^{130}$ See, e.g., Joseph S. Klapach, Note, Thou Shalt Not Politic: A Principled Approach to Section 501(c)(3)'s Prohibition of Political Campaign Activity, 84 CoRnell L. Rev. 504, 506 (describing a charity as having to do a "deal with the IRS" under which "the charity must sacrifice its 'soul"').

${ }^{131}$ See Chisolm, supra note 30, at 332.

${ }^{132} I d$. at 344.

${ }^{133}$ See supra Part I.C (discussing the justifications for and criticisms of the Rule). 
excluding certain activities. The Rule is not primarily about suppressing speech.

Similarly, section 170(c) of the Code is a law enacted to describe the type of organization with respect to which charitable-and so deductible - contributions may be made. ${ }^{134}$ It too is not a law "enacted to control or suppress speech." 135 Both sections of the Code directly implicate speech, to be sure, but their overriding purpose is not to regulate speech.

\section{Purpose of the Rule Viewed as Part of the Tax-Exemption System}

In addition, to decide whether the Political Activities Prohibition of section 501(c)(3) is a law with a purpose of suppressing speech, and thus is a First Amendment case, or is a law with a revenue purpose, and thus a tax case that touches on speech, it is instructive to consider other sections of the Code pertaining to federal income tax exemption. Just as section 441b's purpose is understood in light of the purpose of the FECA to regulate elections, similarly, the purpose of tax exemption and its relationship to partisan activity is better understood by viewing the entire statutory scheme. As the Supreme Court said in the related context of the lobbying limitation of section 501(c)(3): "it is necessary to understand the effect of the taxexemption system enacted by Congress." 136

Importantly, the "tax-exemption system" covers many types of organizations, not just section 501(c)(3) organizations. The law of tax-exempt organizations describes at least twenty-nine types of organizations. ${ }^{137}$ Each type may qualify for a tax treatment that is other than the default treatment for the organization. For example, if an organization incorporates, then as a general matter, it is subject to tax as a corporation under subchapter $\mathrm{C}$ of the Code, unless it can and does elect to be treated differently, or it qualifies for different treatment under one of the exempt organization provisions. Notably, no tax-related political activities prohibition applies to the default treatment of the corporation as a corporation. ${ }^{138}$ Instead, limitations

${ }^{134}$ I.R.C. $\$ 170(c)$ (2006).

${ }^{135}$ Citizens United v. FEC, 130 S. Ct. 876, 896 (2010). added)

${ }^{136}$ Regan v. Taxation with Representation of Wash., 461 U.S. 540, 544 (1983) (emphasis

${ }^{137}$ Section 501(a) of the Code provides exemption from federal income tax to organizations described in section 501(c) or (d) and section 401. I.R.C. § 501(a) (2006). There are more than 29 types of organizations described in section 501(c) and (d), of which section 501(c)(3) organizations are but one type. I.R.C. $§ 501(c)-(d)$. Section 401 of the Code describes various types of pension plans. I.R.C. $\$ 401$.

138 The Electioneering Rule was imposed upon the corporation as a corporation. See infra text accompanying notes 188-90 (explaining that the Electioneering Rule is an entity level rule 
on political activities are a result of a choice of other than the default tax treatment.

Of the many exempt organization types, only one-the section 501(c)(3) organization - is subject to a prohibition on political activities. ${ }^{139}$ Other tax-exempt entities may and do participate in political activity. For example, the social welfare organization described in section 501(c)(4) of the Code is permitted to engage in political activity so long as the activity does not become its principal activity. ${ }^{140}$ In general, this same conceptual approach to political activity applies to other exempt organizations-i.e., absent a prohibition, the activity generally is permitted. Accordingly, for exempt organizations other than section 501(c)(3) organizations, the question of political activity concerns the extent to which political activity may become inconsistent with the organization's exemption type so as to change the nature of the organization and disqualify it from its otherwise applicable tax status.

If an organization crosses a line so that its primary purpose is to influence elections, the "tax exemption system" of the Code has an answer: section 527. Section 527 provides for the tax treatment of political organizations, i.e., an organization that is organized and operated primarily for partisan activity. ${ }^{141}$ Political organizations are defined based entirely on the purpose of the organization (irrespective of organizational form), and the tax treatment follows the definition. $^{142}$ Further, Congress was aware that some exempt organizations might engage in partisan activity but fall short of political organization status. Thus, if an exempt organization (meaning here any of the 29 organization types listed in section

unlike the Political Activities Prohibition).

${ }^{139}$ In general, this means that the activities of a political organization and a charitable organization are mutually exclusive. See supra Part I.C. But at least one activity-attempting to influence the confirmation of judicial appointments-qualifies as a political activity for purposes of section 527 but not as political activity for purposes of section 501(c)(3). I.R.S. Gen. Couns. Mem. 39694 (Feb. 22, 1988).

${ }^{140}$ Rev. Rul. 81-95, 1981-1 C.B. 332; Rev. Rul. 67-368, 1967-2 C.B. 194.

${ }^{141}$ I.R.C. $\$ 527$ (2006).

${ }^{142}$ I.R.C. $\$ 527(\mathrm{a})$, (e)(1). Although political organizations are often referred to as "exempt" organizations, this is mostly a misnomer, due in part to the location of the political organization provisions in the Code in the 500 series and to the terminology of the sectionreferring to "exempt function" and "exempt function income." Section 527 organizations are best viewed as a distinct type of organization for tax purposes, with a special set of tax rules. See generally Roger Colinvaux, Regulation of Political Organizations and the Red Herring of Tax Exempt Status, 59 NAT'L. TAX J. 531 (2006) (describing the tax treatment of section 527 organizations). 
501(c)) spends money on partisan activity, the organization is subject to the tax rules of section $527 .{ }^{143}$

In sum, to a certain extent, with respect to political activity, the "tax exemption system" can be viewed as covering a spectrum of organizations. Section 501(c)(3) organizations, which participate in no political activity, are on one extreme. And section 527 organizations are on the other, participating in unlimited political activity as a primary purpose. Other exempt organizations, which can participate in political activity to the extent that the activity does not subsume the organization, are somewhere in between.

The presence of such an elaborate, if somewhat ad hoc, system sheds light on the purpose of limits on political activity for tax purposes. Beginning with the default, taxable status, there are no tax restrictions on political activity. But if an organization claims an exemption, limitations follow. The limits can be severe or moderate depending upon the nature of the exempt status claimed. The important point, however, is that political activity, and expenses for and income from partisan speech, is and always has been a special subject for the tax law. As an activity, it is neither promoted nor suppressed. The restrictions arise as incidental to the aim of exemption. That is, some other activity (the exempt activity) might be promoted relative to political activity, but suppression of political activity as such is not the goal. Where political activity is relevant, the concerns are whether the activity is consistent with the organization's tax status, the extent to which it is consistent, and the appropriate tax treatment for a completely partisan organization. The only exempt organization facing a prohibition is the section 501(c)(3) organization. This can be explained not only because of special concerns about the politicization of charity, but also because of other tax benefits related to charities - generally unavailable to other exempt organizationssuch as the charitable deduction. ${ }^{144}$

In short, not all entities are treated alike for tax purposes. To the extent the tax law has made distinctions based on political activity, it is not limited to section 501(c)(3) organizations, but covers many others. Arguably, in no case has the purpose of the tax classification and political activity rules been based on a desire to suppress speech. Importantly, to the extent Citizens United calls into question the validity of the Political Activities Prohibition, the impact will be

${ }^{143}$ See I.R.C. $\$ 527(f)(1)$ (providing generally for tax on the lesser of a section 501(c) organization's investment income or the amount spent on political activity).

${ }^{144}$ I.R.C. § 170(a). See also Bazil Facchina et al., Privileges \& Exemptions Enjoyed by Nonprofit Organizations, 28 U.S.F. L. REV. 85 (1993) (describing the benefits accorded to nonprofit organizations). 
much broader, really calling into question the basic decision made by Congress that a partisan activity is significant for tax purposes. ${ }^{145}$

\section{Purpose and Institutional Considerations}

In addition, the respective purposes of the Electioneering Rule and the Political Activities Prohibition play an important role as a background consideration in comparing Citizens United and the hypothetical Our Country posed above in Part II.A. Laws with the purpose of regulating speech are likely to be strongly shaped by the Supreme Court, but laws directed to tax classifications may receive greater deference.

Thus, because the purpose of the campaign finance law is to regulate speech, it is not surprising that the Supreme Court has developed a rich, detailed, complex, and varied jurisprudence in the campaign finance arena. Over the twenty-four year period from the landmark case Buckley v. Valeo ${ }^{146}$ to Citizen's United, there have been no fewer than seventeen Supreme Court opinions on the constitutionality of the campaign finance laws. ${ }^{147}$ Indeed, it is fair to

${ }^{145}$ See supra Part I.A (explaining the reasoning behind Congress's determination that partisan activity is significant for tax purposes).

146424 U.S. 1 (1976).

${ }^{147}$ FEC v. Wis. Right to Life, Inc., 551 U.S. 449 (2007) (ruling that restrictions on corporate spending on election campaign ads that advocate based on issues are subject to strict scrutiny and are unconstitutional); Randall v. Sorrell, 548 U.S. 230 (2006) (holding that Vermont's campaign finance statute violated the First Amendment because it restricted the amounts candidates could spend on their campaigns and restricted the amounts that individuals, organizations, and political parties could contribute to those campaigns); McConnell v. FEC, 540 U.S. 93 (2003) (holding that most soft money provisions of the Bipartisan Campaign Reform Act did not violate free speech and association rights), overruled in part by Citizens United v. FEC, 130 S. Ct. 876 (2010); FEC v. Beaumont, 539 U.S. 146 (2003) (ruling that prohibiting nonprofit advocacy corporations to make direct contributions to federal elections is consistent with the First Amendment); FEC v. Colo. Republican Fed. Campaign Comm., 533 U.S. 431 (2001) (holding that limits on coordinated expenditures of the Federal Election Campaign Act are constitutional as they are not an undue burden); Nixon v. Shrink Mo. Gov't PAC, 528 U.S. 377 (2000) (upholding Missouri's campaign finance law limiting contributions to state political candidates); Col. Republican Fed. Campaign Comm. v. FEC, 518 U.S. 604 (1996) (finding that independent political expenditures by political parties do not violate the Federal Election Campaign Act's restrictions); Austin v. Mich. Chamber of Commerce, 494 U.S. 652 (1990) (upholding a restriction on corporate treasury funding of state candidate elections), overruled by Citizens United, 130 S. Ct. 876; FEC v. Mass. Citizens for Life, Inc., 479 U.S. 238 (1986) (holding that defendant's violation of the Federal Election Campaign Act was trumped by its First Amendment rights and therefore the statute was unconstitutional as applied to defendant); FEC v. Nat'l Conservative Political Action Comm., 470 U.S. 480 (1985) (holding that the provision of the Presidential Election Campaign Fund Act limiting expenditures by political parties was unconstitutional because it violated the First Amendment); FEC v. Nat'l Right to Work Comm., 459 U.S. 197 (1982) (determining who is a member for purposes of the Federal Election Campaign Act); Brown v. Socialist Workers '74 Campaign Comm., 459 U.S. 87 (1982) (holding that the disclosure requirement of an Ohio campaign law was unconstitutional when applied to a minor political party); Bread Political Action Comm. v. FEC, 455 U.S. 577 (1982) (denying expedited review of the Federal Election Campaign Act to 
say that the Supreme Court's constant presence in the campaign finance area has made it a key institutional actor with a vested interest in shaping these laws through its jurisprudence. Since Buckley, the political battles and constitutional questions have been almost ceaseless. Dissenting justices have consistently voiced their opinion that Buckley was wrongly decided. ${ }^{148}$ And it has been common to speculate whether the next case will bring a major shift in the constitutionality of prevailing campaign finance rules. ${ }^{149}$ Despite its high controversy-including accusations that the Court decided a question not properly raised, ${ }^{150}$ and overturned decades of precedent with barely a nod to the importance of stare decisis ${ }^{151}$-Citizens United was not entirely a surprise. The Court has sent signals for years, either through the complexity of its own rulings or through the voices of individual justices, that all was not well with the congressional (and the Federal Election Commission's) approach to the regulation of campaign finance. ${ }^{152}$

By contrast, the purpose of sections 501(c)(3) and 170 is to provide an exemption and a deduction, i.e., to describe organizations

group not listed as eligible in the statute); Citizens Against Rent Control v. City of Berkeley, 454 U.S. 290 (1981) (holding that a limit in an ordinance on the right of association was unconstitutional); FEC v. Democratic Senatorial Campaign Comm., 454 U.S. 27 (1981) (holding that the Federal Election Campaign Act does not foreclose the use of agency agreements); Cal. Med. Ass'n v. FEC, 453 U.S. 182 (1981) (upholding the constitutionality of contribution limits against First and Fifth Amendment challenges); First Nat'l Bank of Bos. v. Bellotti, 435 U.S. 765 (1978) (declaring a state criminal statute that denied corporations the right to make political contributions unconstitutional).

${ }^{148}$ See, e.g., McConnell, 540 U.S. at 248 (Scalia, J., dissenting) (citation omitted) ("I continue to believe that Buckley v. Valeo ... was wrongly decided ...."); Nat'l Conservative PAC, 470 U.S. at 507 (White, J., dissenting) (citation omitted) ("I continue to believe that Buckley v. Valeo ... was wrongly decided.”).

${ }^{149}$ See, e.g., Linda Greenhouse, Supreme Court Set to Weigh Central Election-Law Issues, N.Y. TiMES, Feb. 28, 2006, at A14 (speculating about the upcoming 2006 Supreme Court decision in Randall $v$. Sorrell, wherein a Vermont campaign finance law was challenged); Richard A. Oppel Jr. \& Neil A. Lewis, Campaign Law Set for Big Test In a Courtroom, N.Y. TIMES, Dec. 3, 2002, at A1 (discussing the upcoming 2003 Supreme Court decision in McConnell v. FEC, which involved a challenge to the constitutionality of the McCain-Feingold Act).

${ }^{150}$ Adam Liptak, Justices Turn Minor Movie Case Into a Blockbuster, N.Y. TIMES, Jan. 23, 2010, at A13 (quoting Citizens United v. FEC, 130 S. Ct. 876, 932 (2010) (Stevens, J., dissenting) ("'Essentially,' Justice John Paul Stevens wrote for the dissenters in the 5-to-4 decision, 'five justices were unhappy with the limited nature of the case before us, so they changed the case to give themselves an opportunity to change the law."').

${ }^{151}$ Adam Liptak, Stevens Era, Nearing End, Takes On An Edge, N.Y. TiMES, Jan. 26, 2010, at A12 (quoting Citizens United, 130 S. Ct. 876, 942 (Stevens, J. dissenting) ("In his dissent, Justice Stevens said no principle required overruling two major campaign finance precedents. 'The only relevant thing that has changed since' those decisions, he wrote, 'is the composition of this court."').

${ }^{152}$ See supra notes 148 and accompanying text (discussing skepticism amongst some justices that Buckley v. Valeo was wrongly decided). 
and expenses that for purposes of the tax system are treated differently than others. It should come as no surprise that the jurisprudence of the Supreme Court is much less varied, complex, and voluminous in this area. Here, we are not speaking of the Court's role in exercising judicial review of the Constitution, but rather of Congress's role in raising revenue, and the extent to which the means chosen by Congress implicate constitutional concerns. ${ }^{153}$ Accordingly, tax cases challenging deductions and exemptions generally must overcome the Court's deferential posture: deductions are a matter of legislative grace. ${ }^{154}$

More specifically, Supreme Court cases involving section 501(c)(3) (or its predecessors) are few and far between. The two most relevant cases, Cammarano v. United States ${ }^{155}$ and Regan v. Taxation with Representation of Washington ("TWR"), ${ }^{156}$ are unanimous decisions ${ }^{157}$ that largely and summarily affirm Congress's decision to place limitations on speech in connection with a deduction or an exemption. A third case, Speiser v. Randall, ${ }^{158}$ also is summary by today's standards, but this time in the opposite direction: striking down a state exemption because of its implications on free speech. ${ }^{159}$ Speiser, however, as discussed below, is readily distinguishable from the Cammarano and TWR approach. ${ }^{160}$

In any event, the sparsity of cases places any challenge to the Political Activities Prohibition in a much different political and legal context. Unlike the campaign finance area, in tax cases generally, and section 501(c)(3) cases in particular, the Court does not have a rich history or institutional voice. ${ }^{161}$ In short, the Court is not defending its

${ }^{153}$ See Regan v. Taxation with Representation of Wash., 461 U.S. 540, 550 (1983) (referring to the lobbying limitation as a decision by Congress not to subsidize the activity, the Court concluded, "[w]e have no doubt but that this statute is within Congress' broad power in this area"); see also Galston, supra note 12, at 891-97 (discussing the Court's deferential tax law approach).

${ }^{154}$ E.g., Comm'r v. Sullivan, 356 U.S. 27, 28 (1958) ("Deductions are a matter of grace and Congress can, of course, disallow them as it chooses."); Interstate Transit Lines v. Comm'r, 319 U.S. 590, 593 (1943) ("[W]e examine the argument in the light of the now familiar rule that an income tax deduction is a matter of legislative grace and that the burden of clearly showing the right to the claimed deduction is on the taxpayer."); New Colonial Ice Co. v. Helvering, 292 U.S. 435, 440 (1934) ("Whether and to what extent deductions shall be allowed depends upon legislative grace; and only as there is clear provision therefor can any particular deduction be allowed.").

155358 U.S. 498 (1959).

156461 U.S. 540 (1983).

157 There were concurrences in both cases, discussed infra at text accompanying notes $179-80$ and $245-47$.

158357 U.S. 513 (1958).

${ }^{159} \mathrm{Id}$. at 529.

160 See infra Part II.F.1-2.

161 The canon of Supreme Court cases concerning the charitable tax benefits of the Code 
own turf to the extent it is in the campaign finance arena. Although in Citizens United the Court showed a willingness to overturn settled law, they did so in an area of law-campaign finance-that undergoes constant legislative change and constitutional scrutiny, and arguably, was never all that settled. Further, the Court said that they were in effect forced into a controversial decision in order to resolve a split in their own precedents. ${ }^{162}$ Accordingly, it may be a much different matter institutionally to overturn a rule such as the Political Activities Prohibition - the context is completely different, notwithstanding the facial similarities to the impact on speech.

\section{Sanctions}

In deciding whether the Electioneering Rule was a burden on speech, the Court in Citizens United described certain actions that, if taken, would be subject to the Electioneering Rule:

(1) The Sierra Club runs an ad within 60 days of a general election that tells the public to disapprove of a Congressman who supports logging in national forests;

(2) The National Rifle Association publishes a book urging the public to vote against an incumbent Senator who supports a handgun ban; and

(3) The American Civil Liberties Union creates a website endorsing a presidential candidate on free speech grounds. ${ }^{163}$

Those examples, designed assuredly to highlight the outcome of the Electioneering Rule as censorship of the first order, are each also

are fairly sparse and wide ranging. See, e.g., Bob Jones Univ. v. United States, 461 U.S. 574, 585 (1983) (holding that non-profit private schools that use religious doctrine to racially discriminate cannot qualify as a tax-exempt organization); TWR, 461 U.S. at 551 (granting substantial latitude to Congress for determining which groups can receive tax-exempt status); Walz v. Tax Comm'n of N.Y., 397 U.S. 664, 667 (1970) (affirming New York statute permitting tax exempt status for religious organizations); Better Bus. Bureau of D.C., Inc. v. United States, 326 U.S. 279, 286 (1945) (refusing a tax exemption for an organization that primarily conducted business); Trinidad v. Sagrada Orden de Predicadores, 263 U.S. 578, 582 (1924) (affirming tax exempt status of an organization that directed profits towards science and education).

${ }^{162}$ Citizens United v. FEC, 130 S. Ct. 876, 903 (2010) ("The Court is thus confronted with conflicting lines of precedent: a pre-Austin line that forbids restrictions on political speech based on the speaker's corporate identity and a post-Austin line that permits them.”). But see id. at 938 (Stevens, J., dissenting) ("There was also the straightforward path: applying Austin and McConnell, just as the District Court did in holding that the funding of Citizens United's film can be regulated under them. The only thing preventing the majority from affirming the District Court, or adopting a narrower ground that would retain Austin, is its disdain for Austin.").

${ }^{163} \mathrm{Id}$. at 897. 
likely to violate the Political Activities Prohibition if undertaken by charities. At first glance then, how can the Rule survive?

The facial similarities between the Electioneering Rule and the Political Activities Prohibition diverge not just with respect to purpose but also when the consequences of violating either rule are taken into account. That the Electioneering Rule is overtly "backed by criminal sanctions" was clearly important to the Court. ${ }^{164}$ The above examples, the Court said, "would all be felonies." 165 And although the opinion asserted the importance of protecting the speech of corporations qua corporations, the corporation qua corporation does not go to jail for corporate violations. Rather, only natural persons, i.e., those who knowingly and willfully violate the Electioneering Rule, can go to jail.

That the criminal sanction is important to the Court was evidenced by the repeated references to felonies or crimes throughout the Court's opinion-appearing in each part except Part IV ${ }^{166}$ (the omission in Part IV is to be expected because Part IV upheld the constitutionality of the disclosure provisions). Indeed, the Court concluded in Part V that "it seems stranger than fiction for our Government to make this political speech a crime. Yet this is the statute's purpose and design." speech is a critical part of the campaign finance statutory and regulatory scheme and an important factor in the Court's decision.

As such, the Electioneering Rule's sanction is an important basis for distinction with the Political Activities Prohibition. The prohibition often is referred to, somewhat redundantly, as

${ }^{164} I d$.

${ }^{165}$ Id. See 2 U.S.C. $\$ 437 \mathrm{~g}(\mathrm{~d})(1)(\mathrm{A})$ (2006) ("Any person who knowingly and willfully commits a violation of any provision of this Act which involves the making, receiving, or reporting of any contribution, donation or expenditure" shall be fined or imprisoned or both.).

166 See Citizens United, 130 S. Ct. at 888 (noting that Citizens United "feared" that Hillary involved independent expenditures "thus subjecting the corporation to civil and criminal penalties"); id. at 889 (dismissing the ACLU's argument as amici regarding how to interpret the electioneering communication definition in part because an inaccurate determination under their definition would "potentially subject[] the speaker to criminal sanctions"); id. at 895 ("[A] speaker who wants to avoid threats of criminal liability and the heavy costs of defending against FEC enforcement must ask a governmental agency for prior permission to speak."); id. at 897 ("The law before us is an outright ban, backed by criminal sanctions."); id. at 897 (noting that "[s]ection 441b makes it a felony for all corporations-including nonprofit advocacy corporations" to engage in political speech); id. at 897 (giving examples of what would be a felony under section 441b); id. at 903 (noting that a violation of the Michigan law at issue in Austin "was punishable as a felony"); id. at 904 ("If the First Amendment has any force, it prohibits Congress from fining or jailing citizens, or associations of citizens, for simply engaging in political speech."); id. at 908 ("When Government seeks to use its full power, including the criminal law, to command where a person may get his or her information or what distrusted source he or she may not hear, it uses censorship to control thought.").

${ }^{167} I d$. at 917 . 
"absolute,"168 meaning that a single instance of political activity violates the Rule. Violation is not, however, a felony. Rather, the consequence for violation is revocation of the organization's charitable status. ${ }^{169}$ The organization also is barred from reorganizing as a tax-exempt social welfare organization under section 501(c)(4) of the Code. ${ }^{170}$

In addition to revocation, if expenditures are involved in the political activity, excise taxes may be assessed. ${ }^{171}$ There is an excise tax on the organization equal to 10 percent of the expenditure $(100$ percent if not corrected in a certain amount of time), and an excise tax on an organization manager equal to 2.5 percent of the expenditure (50 percent if the manager refused to agree to part or all of the correction) if the manager knowingly agreed to make the expenditure. ${ }^{172}$ Flagrant violations of the Rule may result in expedited enforcement action. ${ }^{173}$

In short, the difference in consequence between the Electioneering Rule and the Political Activities Prohibition are significant. One

${ }^{168}$ See Kindell \& Reilly, supra note 40, at 352 (discussing Seventh and Second Circuit cases holding the prohibition to be absolute and noting that an organization violates it even if political participation is not a "substantial part" of the group's overall activities). The reason for the redundancy is that words, especially in statutes, often do not mean what they seem to say. For example, section 501(c)(3) organizations must be "exclusively" organized and operated for exempt purposes. I.R.C. § 501(c)(3) (2006). But "exclusively" turns out to mean "primarily" in the regulations. Treas. Reg. $\$ 1.501$ (c)(3)-1 (as amended in 2008). This illustrates the need for emphasis when describing the Political Activities Prohibition as absolute-the statute really does mean what it says. Of course, this turns out not to be entirely correct either, as the recent IRS reports on enforcement of the Political Activities Prohibition demonstrate. See also IRS, Political Activities Compliance Initiative Executive Summary 3-4 (2006) (reporting violations of the prohibition but no sanction).

${ }^{169}$ See IRS, POlitical Activities Compliance Initiative Executive Summary 2 (2006) (indicating that sanctions for violating the prohibition are limited to fines and revocation).

${ }^{170}$ I.R.C. $\$ 504(a)$. The inability to reorganize as a section 501(c)(4) organization does not apply to churches. Id. at $\S 504$ (c). The court in Branch Ministries v. Rossotti, 211 F.3d 137, 142-43 (D.C. Cir. 2000), cited this factor as part of its reasoning that the sanction, at least with respect to churches, was not especially onerous.

${ }^{171}$ I.R.C. $\S 4955$. The text of section 4955 suggests that the excise tax is not an intermediate sanction, but rather is to be levied in addition to revocation of charitable status. The legislative history, however, sends mixed signals - it states that the sanction is not intended to weaken the absolute character of the prohibition, but also indicates that in certain limited cases, the IRS may have the discretion to use the excise tax in lieu of revocation. H.R. Rep. No. 100391 , pt. 2, at 1624 (1987).

${ }^{172}$ I.R.C. $\$ 4955$.

${ }^{173}$ See I.R.C. $\S 6852$ (a) (providing that if a section 501(c)(3) organization flagrantly violates the prohibition against political expenditures, "the Secretary shall immediately make a determination of any income tax payable by such organization ... and shall immediately make a determination of any tax payable under section 4955 by such organization"); I.R.C. $§ 7409$ (providing that if a section 501(c)(3) organization violates the prohibition on political expenditures and meets certain requirements, a civil action can be commenced to enjoin it from making any further expenditures). 
makes speech a crime while the other makes speech a disqualification for an organization-level tax exemption and possibly exposes the organization and its managers to monetary penalties if expenditures are involved. Measured as a form of suppression, the Electioneering Rule's direct threat of criminal sanctions likely suppresses the speech of many, in accordance with its design, while the threat of loss of tax exemption, though important, is of a different order.

\section{A Ban on Speech}

A third factor important to the Citizens United Court was its characterization of the Electioneering Rule as a ban on speech. The Court said that the Electioneering Rule is a ban "notwithstanding the fact that a PAC created by a corporation can still speak." 174 The Court noted that a "PAC is a separate association from the corporation." 175 Therefore, the Court said, the availability of the option to speak through a PAC does not allow the corporation to speak. ${ }^{176}$ Setting aside the implications of the assertion that a PAC is a separate association, the point the Court made is quite clear and dovetails with its concern that corporations as corporations are worthy of protection. In effect, what the Court was saying is that speech of the corporation's PAC is not the same as speech by the corporation, and therefore, the ban is a ban.

The Citizens United Court's conclusion that the Electioneering Rule was a "ban on speech," 177 despite the availability of a PACspeech option, appears to have rather ominous implications for the Political Activities Prohibition and other tax rules limiting the lobbying and political activity of charities and other exempt organizations. Since the Court's 1983 decision in TWR, it has been

${ }^{174}$ Citizens United v. FEC, 130 S. Ct. 876, 897 (2010). "PAC" is short for political action committee.

${ }^{175} I d$. (emphasis added).

${ }^{176} \mathrm{Id}$. And even if it did, the Court said that the formation of a PAC is a burdensome alternative as "they are expensive to administer and subject to extensive regulations." Id. The Court cited the fact that "every PAC must appoint a treasurer, forward donations to the treasurer promptly, keep detailed records of the identities of the persons making donations, preserve receipts for three years, and file an organization statement and report changes to this information within 10 days" in addition to filing detailed monthly reports with the FEC and that "PACs have to comply with these regulations just to speak." Id. It is hard to know what to make of the Court's burden argument in an exempt organization context. The reporting obligations of section 527 organizations that are not political committees, and so not subject to FEC rules, mirror the FEC requirements. I.R.C. § 527(j) (2006). A political organization too must comply with very similar regulations "just to speak." The implication is that record-keeping and ongoing reporting rules may be unconstitutional. But this part of the Court's opinion appears to be dicta, as the Court merely adds the burden argument after it already has concluded that the PAC option is not a sufficient alternative. Citizens United, $130 \mathrm{~S}$. Ct. at 897.

${ }_{177}$ Citizens United, 130 S. Ct. at 898. 
commonly understood that segregating speech by use of a PAC or an affiliated organization was an important means to inoculate a rule affecting speech from a constitutional challenge. Justice Rehnquist's majority opinion in $T W R$ referred to such an alternate channel approvingly. ${ }^{178}$ Justice Blackmun's concurrence in TWR (joined by two other Justices) was based on the availability of the affiliate structure, and the fact that the IRS did not require more than separate incorporation and minimal record keeping to ensure that taxdeductible contributions were not used for lobbying. ${ }^{179}$ Indeed, the one court to consider (and uphold) the constitutionality of the Political Activities Prohibition cited TWR, concluding that a section 501(c)(3) organization had a suitable alternate channel for political activity because a section 501(c)(3) organization could set up an affiliated section 501(c)(4) organization, which in turn could establish a related PAC or political organization to conduct political activity. ${ }^{180}$ Of course, the section 501(c)(3) organization must take steps to ensure that the political activities of the PAC are not attributable to the section 501(c)(3) organization.

Thus, the Court's statement in Citizens United that a PAC is a separate association insufficient to speak for the corporation is hard to square with the Court's statements about alternate channels in the tax context. Indeed, directly applying the Court's statements to the tax context seems to go against separate incorporation as a panacea. Rather, it seems to require that the speech of any separate but related organization be attributable to the original organization.

One possibility is that the Court's thinking on alternate channels in the tax context has quite simply changed. If so, however, it does not necessarily follow that the Political Activities Prohibition (and for that matter the lobbying limitation) is suddenly unconstitutional. The presence of a sufficient alternate channel seems to be part of the constitutional analysis. ${ }^{181}$ But the extent to which an alternate channel for speech was necessary given Congress's broad power to make subsidy decisions has never been clear. ${ }^{182}$

178461 U.S. 540, 544 (1983).

${ }^{179}$ Id. at 553 (Blackmun, J., concurring).

${ }^{180}$ Branch Ministries v. Rossotti, 211 F.3d 137, 143 (D.C. Cir. 2000).

${ }^{181}$ See Miriam Galston, Campaign Speech and Contextual Analysis, 6 FIRST AMEND. L. REV. 100, 113-17 (2007) (noting that in FCC v. League of Women Voters, 468 U.S. 364 (1984), Rust v. Sullivan, 500 U.S. 173 (1991), and several district and appellate court cases, the existence of an alternate channel for lobbying is seen as important to the reasoning of $T W R$ ).

182 Professor Galston explained that subsequent courts have pointed to an alternate channel analysis. Id. But the presence or absence of an alternate channel seems more like a factor to be considered when analyzing whether a rule burdens speech than a rule of constitutional law. Perhaps the most important point here is that the majority opinion in TWR noted but did not emphasize the alternate channel. 461 U.S. at 544. 
Further, the Court's statement regarding the insufficiency of PACs is perhaps best viewed in connection with the nature of the Electioneering Rule as a ban on corporate-level speech. Under such a rule, the corporation as corporation was simply prevented (under threat of criminal sanction) from speaking. But it is different for section 501(c)(3) organizations. The Political Activities Prohibition does not prevent the organization from speaking as such (that is, the prohibition is not an entity-level rule); rather it prevents the organization from speaking as a section 501(c)(3) organization.

This is not just a matter of semantics. The distinction between an entity-level rule and a tax classification-level rule may be significant for the alternate channel analysis under the First Amendment. In the tax context, the "organization" can be viewed more broadly than the tax classification, that is, the several tax-exemption provisions work as a whole to provide for organization or entity-level speech for tax purposes. ${ }^{183}$ The question is whether there is some way for the organization to speak, if not as a section 501(c)(3) organization, then as something else like a social welfare organization or a PAC. ${ }^{184}$ Thus, a section 501(c)(3) should not be viewed in isolation but in connection with other tax-exemption provisions. ${ }^{185}$ Under the Electioneering Rule, there was no similar alternate structure available, because the ban was an organization-level ban. In other words, the Court in the past has not, and even in the future might not, view a PAC or a social welfare organization as "separate" for purposes of an alternate channel analysis in the tax-exempt organization context.

\section{E. Identity Discrimination}

Citizens United is notable for its elevation of the corporate form as worthy of virtually the same First Amendment protection as individuals. The Court said:

[T] he Government may commit a constitutional wrong when by law it identifies certain preferred speakers. By taking the right to speak from some and giving it to others, the Government deprives the disadvantaged person or class of the right to use speech to strive to establish worth, standing, and

${ }^{183}$ See, e.g., Galston, supra note 181 , at 103 (discussing, throughout the article, a "network" approach to political activity by tax-exempt organizations).

${ }^{184}$ See infra Part III for additional discussion of the sufficiency of the alternate channel with respect to political activities.

${ }^{185}$ See also supra Part II.B.2 (arguing the the tax-exemption system as a whole must be taken into account in determining the purpose of section 501(c)(3) and the Political Activities Prohibition). 
respect for the speaker's voice. The Government may not by these means deprive the public of the right and privilege to determine for itself what speech and speakers are worthy of consideration. The First Amendment protects speech and speaker, and the ideas that flow from each. ${ }^{186}$

The Court concluded that corporations, as corporations, have a viewpoint and a right to speak. ${ }^{187}$ Thus, the Electioneering Rule wrongfully singled out the corporation for speech suppression.

Once again, on its face, the tenor of the Court's words strongly suggest that the Political Activities Prohibition is problematic. If Congress shall make no law singling out certain groups to suppress their speech, then surely, in adding the Political Activities Prohibition to section 501(c)(3) in 1954, Congress targeted section 501(c)(3) organizations for speech suppression just as surely as the Electioneering Rule singled out corporations and barred their speech.

Yet it is not so straightforward. As a ban on corporate speech, the Electioneering Rule applies at the entity level. ${ }^{188}$ The corporate form is generic and a creature of state law. Corporations can and do have many purposes and functions. The corporate form is an archetype of essential legal forms and is considered a "person" for many purposes. ${ }^{189}$ In short, the corporation is a foundational category of the legal system. Whether or not one agrees that corporations should have the same speech rights as natural persons, it seems indisputable that the corporate form organizationally is fundamental and that a rule targeting the speech of a corporation is directed at a core identity of the legal system.

By contrast, section 501(c)(3) ${ }^{190}$ is a creature of federal tax law-a tax classification ${ }^{191}$ - and not an organizational form. The purposes of a section 501(c)(3) organization are not generic but limited. Because so many organizations take advantage of the tax classification, there are of course many section 501(c)(3) organizations, ${ }^{192}$ and section

\footnotetext{
${ }^{186}$ Citizens United v. FEC, 130 S. Ct. 876, 899 (2010).

${ }^{187} \mathrm{Id}$. at 913 . Rule).

${ }^{188}$ See supra Part II.D (discussing the entity speech prohibition of the Electioneering

${ }^{189}$ See, e.g., I.R.C. $\$ 7701(\mathrm{a})(1)$ (2006) ("The term 'person' shall be construed to mean and include an individual, a trust, estate, partnership, association, company or corporation.").

${ }^{190}$ Section 501(c)(3) applies to "[c]orporations, and any community chest, fund, or foundation.” I.R.C. $\S 501(\mathrm{c})(3)$.

${ }^{191}$ As a general rule, Congress' tax classifications enjoy a " "presumption of constitutionality" that "can be overcome only by the most explicit demonstration that a classification is a hostile and oppressive discrimination against particular persons and classes." Regan v. Taxation with Representation of Wash., 461 U.S. 540, 547 (1983) (quoting Madden v. Kentucky, 309 U.S. 83, 88 (1940)).

${ }^{192}$ See supra note 106 and accompanying text (noting that there are more than 1.5 million
} 
501(c)(3) organizations certainly form an important part of the economy and society. But the widespread use of section 501(c)(3) does not change its character as a tax classification. As such, the Political Activities Prohibition does not target the speech of section 501(c)(3) organizations as organizations as did the Electioneering Rule. Rather, the Political Activities Prohibition is a condition to receive a particular tax status, not a prohibition directed to the organization per se. ${ }^{193}$ Thus, importantly, although section 501(c)(3) status formally does not survive political speech, the entity retains its identity as a corporation (assuming it was so organized) and may speak. In short, the Political Activities Prohibition is best viewed as a condition of a tax classification and not an identity-based restriction, at least not in the same sense of the Electioneering Rule. Concluding otherwise would extend the Court's concern about identity-based bans on speech beyond the entity level to cover other, arguably lesser, identities such as tax classifications. In other words, if a tax classification has the same First Amendment standing as the more generic legal concept of a corporation, it is not clear where the identity line stops, making speech-based, and perhaps other, distinctions because of tax status problematic.

\section{F. Existing Jurisprudence Supports the Political Activities Prohibition}

On the surface there is language in Citizens United that suggests existential (neigh constitutional) peril for the Political Activities Prohibition. At one point, the Court said bluntly: "No sufficient governmental interest justifies limits on the political speech of nonprofit or for-profit corporations." ${ }^{, 194}$ Facially, there appears to be no contest: a charity typically is a nonprofit corporation and the Political Activities Prohibition is a limit on political speech and therefore, the prohibition is unconstitutional. But, as argued above, such a conclusion is too quick.

registered charities, excluding churches).

${ }^{193}$ It is an interesting question whether a state, in response to Citizens United, could amend its corporate code to impose an independent expenditure prohibition as a condition of corporate existence (presumably on a going forward basis). Even though states may be unlikely to do this, such a prohibition would still seem to run afoul of Citizens United. Unlike a condition on a tax classification, violation of such a condition would terminate the corporate existence altogether, which, given the Court's support for the corporate legal form per se, would likely be an unconstitutional result.

${ }^{194}$ Citizens United v. FEC, 130 S. Ct. 876, 913 (2010). 
Purpose, sanction, and a ban on corporate speech are the factors that moved the Court in Citizens United to conclude that the Electioneering Rule was a burden on speech and therefore that strict scrutiny applied. ${ }^{195}$ With respect to each factor, the hypothetical Our Country and the Political Activities Prohibition is distinguishable from Citizens United and the Electioneering Rule. ${ }^{196}$ The purpose of the Political Activities Prohibition is not to suppress speech, but to define charity; the legal setting is tax and not campaign finance; violation of the Political Activities Prohibition is not criminal; the Political Activities Prohibition is by nature a rule associated with a tax status (with, or without, a sufficient alternate channel) rather than a ban on corporate speech. These comparisons form the funnel through which the initial and most important conclusion will be made: Is the Political Activities Prohibition a burden on speech? As shown above, on each factor, Citizens United is distinguishable from Our Country. ${ }^{197}$

Furthermore, the Court would not decide Our Country in a legal vacuum. The Court previously has concluded, twice, in Cammarano and $T W R$, that a restriction that affects speech in connection with a tax benefit does not burden speech. ${ }^{198}$ The Court, however, also concluded the opposite in Speiser. ${ }^{199}$ Accordingly, even though plausible arguments can be made distinguishing Our Country from Citizens United, Our Country must be positioned within existing Supreme Court jurisprudence of Speiser, Cammarano, and TWR.

\section{The Rules of Speiser, Cammarano, and TWR.}

Chronologically, Speiser is the first of the decisions, and the outlier. At issue was a provision of the California constitution, which provided a property tax exemption to veterans. ${ }^{200}$ In order to claim the exemption, veterans were required to complete a standard application form which included the following oath: "I do not advocate the overthrow of the Government of the United States or of the State of

195 See supra text accompanying note 121.

196 See supra Parts II.B-D.

${ }^{197}$ See supra Parts II.B-D.

${ }^{198}$ Regan v. Taxation with Representation of Wash., 461 U.S. 540, 546 (1983) ("Congress has not infringed any First Amendment rights or regulated any First Amendment activity. Congress has simply chosen not to pay for TWR's lobbying."); Cammarano v. United States, 358 U.S. 498, 513 (1959) ("Petitioners are not being denied a tax deduction because they engage in constitutionally protected activities, but are simply being required to pay for those activities entirely out of their own pockets, as everyone else engaging in similar activities is required to do under the provisions of the Internal Revenue Code.").

${ }^{199}$ Speiser v. Randall, 357 U.S. 513, 518 (1958) ("To deny an exemption to claimants who engage in certain forms of speech is in effect to penalize them for such speech.").

${ }^{200} \mathrm{Id}$. at $514-15$. 
California by force or violence or other unlawful means, nor advocate the support of a foreign government against the United States in event of hostilities." 201 The Court acknowledged that "[i]t is settled that speech can be effectively limited by the exercise of the taxing power" but held that "[t]o deny an exemption to claimants who engaged in certain forms of speech is in effect to penalize them for such speech." 202 Additionally, the Court said that "the denial of a tax exemption for engaging in certain speech necessarily will have the effect of coercing the claimants to refrain from the proscribed speech. The denial is 'frankly aimed at the suppression of dangerous ideas." ${ }^{203}$ Accordingly, the Court held that the loyalty oath was an unconstitutional condition of a tax exemption. ${ }^{204}$

By contrast, one year later, in Cammarano, the Court considered the validity of a Treasury Regulation (now codified in section 162(e) of the Code) that disallowed a deduction for ordinary and necessary business expenses if the expense was for lobbying. ${ }^{205}$ Although like Speiser, a rule of tax had the effect of limiting speech, the Court unanimously concluded that "Speiser ha[d] no relevance." petitioners in Cammarano, the Court said were "not being denied a tax deduction because they engage in constitutionally protected activities, but are simply being required to pay for those activities entirely out of their own pockets. ${ }^{207}$ Accordingly, a SpeiserCammarano dichotomy emerged: Is the rule "aimed at the suppression of dangerous ideas," ${ }^{208}$ or is it just a decision not to subsidize a protected activity? If the former, then there is a burden on speech; if the latter, there is no burden.

In the 1983 decision, TWR, the Court considered whether conditioning tax-exempt status under section 501(c)(3) of the Code on refraining from substantial lobbying activity was constitutional. ${ }^{209}$ The Court said that the unconstitutional condition model of Speiser was not the right one:

The Code does not deny TWR the right to receive deductible contributions to support its non-lobbying activity, nor does it deny TWR any independent benefit on account of its

${ }^{201} I d$. at 515

${ }^{202} I d$. at 518 (citations omitted).

${ }^{203}$ Id. at 519 (quoting Am. Comm'ns Assn. v. Douds, 339 U.S. 382, 402 (1950)).

${ }^{204} I d$. at 529.

${ }^{205}$ Cammarano v. United States, 358 U.S. 498, 499-500 (1959).

${ }^{206} I d$. at 513.

${ }^{207} I d$.

${ }^{208}$ Speiser, 357 U.S. at 519 (quoting Am. Comm'ns Assn., 339 U.S. at 402) (internal quotation marks omitted).

${ }^{209}$ Regan v. Taxation with Representation of Wash., 461 U.S. 540, 541 (1983). 
intention to lobby. Congress has merely refused to pay for the lobbying out of public moneys. This Court has never held that Congress must grant a benefit such as TWR claims here to a person who wishes to exercise a constitutional right. ${ }^{210}$

Noting that it would be a different case if the rule was "aim[ed] at the suppression of dangerous ideas," that the statute was intended to suppress any ideas or any demonstration that it has had that effect."212 Accordingly, the Court said the case was controlled by Cammarano and upheld the lobbying rule. ${ }^{213}$

\section{The Speiser-Cammarano-TWR Trilogy Discussed.}

This trilogy of cases requires some discussion. Notably, because Speiser came first, the Court in Cammarano and TWR had to articulate a distinction, which the Court did, but in a somewhat conclusory fashion. The key statement in Cammarano, that "[p]etitioners are not being denied a tax deduction because they engage in constitutionally protected activities," ${ }^{214}$ seems in one sense incorrect. From the petitioners' standpoint, it appears that they are being denied a tax deduction because of a special rule that targets constitutionally protected activities. Were it not for the rule, a deduction generally would be available. Similarly, Justice Rehnquist's statement in TWR quoted above that the statute "does not deny TWR the right to receive deductible contributions to support its nonlobbying activity" or "deny TWR any independent benefit on account of its intention to lobby" 215 is very hard to make sense of on its terms. The Code does deny TWR the right to receive deductible contributions if TWR lobbies to a substantial extent. Further, the Code does deny TWR an independent benefit - that of tax exemption-if TWR intends to substantially lobby. ${ }^{216}$

${ }^{210} \mathrm{Id}$. at 545.

${ }^{211} I d$. at 548 (quotations and citations omitted).

${ }^{212} \mathrm{Id}$. Arguably, this statement may provide a footing for an as-applied challenge to the Political Activities Prohibition. The reference to the "effect" of the provision invites an argument that the result of the Rule has been to suppress ideas.

${ }^{213} I d$. at 546.

${ }^{214}$ Cammarano v. United States, 358 U.S. 498, 513 (1959).

215461 U.S. at 545.

${ }^{216}$ In his concurrence in TWR, Justice Blackmun specifically notes this part of Justice Rehnquist's opinion and says that it can only make sense if the alternate structure of unlimited lobbying through an affiliated organization is permitted. Id. at 553 (Blackmun, J., concurring). In such a case, TWR can continue to be eligible to receive deductible contributions with respect to its non-lobbying activity and get the benefit of charitable exemption, notwithstanding the lobbying of a controlled affiliate. 
Nevertheless, although the Court's statements in Cammarano and $T W R$ are not clear explanations of the Court's reasoning, there is an important and controlling, if somewhat fuzzy, distinction drawn with Speiser: the purpose of the law. Really, the statements quoted in Cammarano and TWR are the Court's effort to state that the rules of the federal tax code had a different purpose from the state rule at issue in Speiser and that the difference was constitutionally significant. Yes, speech is burdened as a practical matter in each case, but only in Speiser was the purpose of the rule to burden speech, i.e., it was "“frankly aimed at the suppression of dangerous ideas.",217

To see this, further discussion of Speiser is necessary. One aspect of Speiser that is often overlooked is that the Court assumed without deciding that California had the power to "deny tax exemptions to persons who engage in the proscribed speech for which they might be fined or imprisoned." ${ }^{18}$ Thus, the Court did not address the question of the constitutionality of the loyalty oath as a condition of property tax exemption as such. Instead, the Court invalidated the oath on procedural due process grounds because the method California used to enforce the oath was unfair. ${ }^{219}$

In Speiser, the Court was moved because the California law in effect was established to force veterans to prove a substantive question: namely, their loyalty to the regime. ${ }^{220}$ Merely signing the oath was not enough to satisfy the burden; rather, it was "but a part of the probative process by which the State [sought] to determine which taxpayers [fell] into the proscribed category." 221 And the State could subpoena applications and investigate whether the veterans were "proper persons" to qualify for tax exemption. ${ }^{222}$ The Court likened the loyalty oath and its process of proof to a legislature declaring a person guilty of a crime, and then making them prove their innocence. ${ }^{223}$ Thus, "[t]he question for decision ... [was] whether this allocation of the burden of proof" met due process demands. ${ }^{224}$ Although putting the burden on the taxpayer normally raises no concerns, the Court found that this case was different because "the purported tax was shown to be in reality a penalty for a crime,"225

${ }^{217}$ Speiser v. Randall, 357, U.S. 513, 519 (1957) (quoting Am. Comm'ns Assn. v. Douds, 339 U.S. 382, 402 (1950)).

$218 \mathrm{Id}$. at 520.

${ }^{219} \mathrm{Id}$. at 529.

${ }^{220} \mathrm{Id}$. at 528 .

${ }^{221} \mathrm{Id}$. at 522.

${ }^{222} \mathrm{Id}$. at 521-22.

${ }^{223}$ Id . at 523-24.

${ }^{224} \mathrm{Id}$. at 523.

${ }^{225} \mathrm{Id}$. at 525 . 
and, as the Court had noted earlier, the speech in question here was a crime. ${ }^{226}$ In such a case, greater procedural safeguards are required "than when only the amount of [the taxpayer's] tax liability is in issue." $" 227$

In sum, what the State of California attempted by the loyalty oath was to establish through the tax exemption system a method to flush out potential criminals. The law was a direct attempt to suppress the speech of a particular class of persons. This was its purpose. But there would be a different result, the Court said, if the "purpose was to achieve an objective other than restraint on speech."

The contrast to the Political Activities Prohibition and lobbying limitations of sections 501(c)(3) and 162(e) is notable. Perhaps, in the Court's view, the self-evident nature of the contrast explains the Court's fairly conclusory approach to distinguishing Speiser in both cases. As discussed above, Congress's purpose for the tax rules is not related directly to speech. ${ }^{229}$ As the Court said in Cammarano, the nondeductibility of lobbying expenses is a "sharply defined national policy," 230 a provision of general applicability, extant for "more than 40 years." 231 Additionally, it said that "[n]ondiscriminatory denial of deduction ... is plainly not 'aimed at the suppression of dangerous ideas." ${ }^{232}$ Regarding the lobbying limitation on section 501(c)(3) status, the Court said in TWR: "Congress has not infringed any First Amendment rights or regulated any First Amendment activity. Congress has simply chosen not to pay for TWR's lobbying." 233 Also, it said that "Congress chose not to subsidize lobbying as extensively as it chose to subsidize other activities that nonprofit organizations undertake to promote the public welfare." 234

Arguably beyond dispute is that the key distinction between Cammarano and Speiser is the purpose of the law. In Speiser, the State set out to deny speech. But, the Court in Cammarano said that Congress had a revenue purpose in mind when enacting the lobbying limitations of sections $162(\mathrm{e})$ and $501(\mathrm{c})(3){ }^{235}$ Thus, the otherwise somewhat cryptic statements above in Cammarano about not denying

${ }^{226} I d$. at 519.

${ }^{227} \mathrm{Id}$. at 525 .

${ }^{228} \mathrm{Id}$. at 527.

229 See supra Part II.B.1.

${ }^{230}$ Cammarano v. United States, 358 U.S. 498, 508 (1959). The Court said this twice. The second time it incorporates the non-subvention/no subsidy rationale of Slee v. Commissioner. Id. at 512 (citing Slee v. Commissioner, 42 F.2d 184, 185 (2d. Cir. 1930)).

${ }^{231} \mathrm{Id}$. at 508 .

${ }^{232}$ Id. at 513 (quoting Speiser, 357 U.S. at 519).

${ }^{233}$ Regan v. Taxation with Representation of Wash., 461 U.S. 540, 546 (1983).

${ }^{234} \mathrm{Id}$. at 544.

${ }^{235}$ See id. at 546 (noting that "Congress has simply chosen not to pay for . . l lobbying"). 
benefits or rights but merely refusing to pay for lobbying are really just the Court's affirmations of an accepted congressional purpose.

Speiser is also distinguishable from the hypothetical Our Country in other important ways. Applying the constitutional conditions doctrine in Speiser, the Court intimates that the loyalty oath bore no relation to the benefit provided, i.e., the oath was "external" to the benefit. ${ }^{236}$ By contrast, the Political Activities Prohibition (and the lobbying limitation) is a condition that is "internal" to the benefit, or rationally related to it. In other words, demanding loyalty has nothing intrinsically to do with providing a property tax exemption. But demanding nonpartisanship is related to determining the type of benefit to be provided, e.g., delivery of charitable or educational goods and services without the distraction of partisan politics. In addition, Speiser, like Citizens United, also appeared to qualify as an identity-based speech restriction. The loyalty oath applied to veterans. A veteran is a veteran is a veteran- "though he be denied a tax exemption, he remains a veteran." 237 Thus, the Court stressed that California had singled out veterans, and conditioned their speech. ${ }^{238}$ By contrast, section 501(c)(3) organizations are a creature of the tax code, and the condition is related to that tax status. That is, if a section 501(c)(3) organization be denied a tax exemption, it remains an organization.

In sum, under the Speiser-Cammarano-TWR dichotomy, purpose arguably is the most significant factor in determing whether a rule (be it a condition or not) burdens speech. Although Speiser involved a condition to exemption (the loyalty oath), this condition has a different purpose from the federal conditions relating to exemption and lobbying. The hypothetical Our Country, distinguishable from Citizens United on the key factors of purpose, sanction, and a ban on the corporate form, fits squarely in the Cammarano-TWR line. Under this line, the Court is likely to conclude that the Political Activities Prohibition is not a burden on speech. A case from the campaign finance context, Federal Election Commission v. Massachusetts Citizens for Life, Inc. ("MCFL"), ${ }^{239}$ underlines this point. In $M C F L$, Justice Brennan easily concluded in discussing $T W R$, that the lobbying restriction of section 501(c)(3) "would infringe no protected activity, for there is no right to have speech subsidized by the Government." 240 Accordingly, despite the fact that the Electioneering

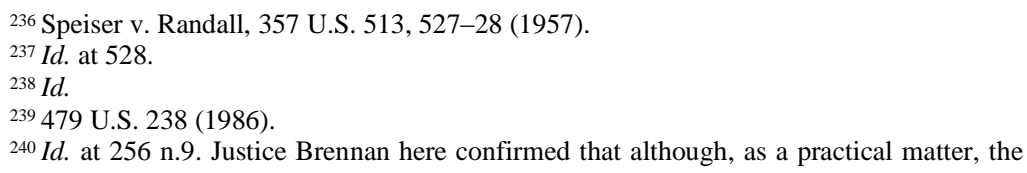


Rule and the Political Activities Prohibition have the effect of suppressing speech, the two rules may nonetheless fairly be characterized as involving in one case but not the other a burden of a fundamental right. ${ }^{241}$

\section{CAUTIONARY NoteS AND THE RELEVANCE OF THE CHARITABLE DEDUCTION}

The analysis in Part II of this Article is intended to show that as a matter of law the Court in deciding Our Country could and should distinguish Citizens United, follow the established Cammarano-TWR model, and hold that the Political Activities Prohibition is consistent with the Constitution. That said, there are enough facial similarities between the Electioneering Rule and the Political Activities Prohibition, and questions raised by the case law, potentially to tip the scales on the fairly nuanced inquiry into whether a rule burdens speech for First Amendment purposes. Or, in the alternative, perhaps the Court could be led to conclude that the Political Activities Prohibition can survive a facial challenge, but not an as-applied challenge. This Part examines factors that perhaps could lead the Court to such conclusions. As argued below, however, even if the Court took either approach, the impact would be slight. This is because a separate constitutional analysis is required for the Political Activities Prohibition for tax exemption under section 501(c)(3) and for tax deduction under section 170. Any possible constitutional infirmities that may exist with respect to section 501(c)(3) do not exist with respect to section 170 .

Political Activities Prohibition affects speech, it does not follow as a legal conclusion that it is a rule that "suppresses speech" as such, rather, it suppresses subsidized speech.

${ }^{241}$ Furthermore, even if the Court concluded that the Political Activities Prohibition was a burden on speech, and that strict scrutiny applied, there is still a case to be made that defining charity as exclusive of political activity serves a compelling state interest. See Steffen N. Johnson, Of Politics and Pulpits: A First Amendment Analysis of IRS Restrictions on the Political Activities of Religious Organizations, 42 B.C. L. REV. 875, 890 (2001) (discussing the possible justification that a limited charity definition serves the State's interest in not compelling taxpayers to subsidize political speech). Although it is outside the scope of this article to make such a case, for all the reasons discussed above, plus the additional loss of revenue to the Treasury, and the difficulty administering any alternative scheme, see infra Part IV, the status quo is defensible as a compelling policy with an indirect effect on speech. But see Houck, supra note 25 , at 86 (arguing that "we limit charities in politics because we don't believe in our gut that they belong there"). 


\section{A. Purpose to Penalize Speech}

Justice Douglas' concurrence in Speiser highlights one fault line. In Speiser, Justice Douglas emphasized his agreement with the Court that the loyalty oath was problematic because it placed an unacceptable burden on citizens to prove their loyalty, contrary to the presumption of innocence. ${ }^{242}$ But he also expressed a concern that if the California rule was aimed "not to apprehend criminals but to penalize advocacy, it likewise must fall." $" 243$ To the extent the hypothetical Our Country Court views the Political Activities Prohibition not as a decision not to subsidize speech, but rather as an effort to penalize advocacy, this argument could carry greater force.

The main support for such a view would likely come from the direct legislative history of the Political Activities Prohibition. Certainly, the circumstantial evidence of its enactment suggests that Senator Johnson shoved through the prohibition in response to an electoral attack by a putative charitable organization. ${ }^{244}$ But, as argued in Part I of this Article, the better view of the Rule is to acknowledge it as the codification of a decision that was decades in the making, one that largely confirmed initial instincts that the meaning of charity is nonpolitical and education does not include propaganda. Further, as argued in Part II.B. 2 of this Article, Congress's treatment of advocacy generally under the Code's tax-exempt organization provisions suggests that penalizing advocacy is not a purpose of the tax treatment.

\section{B. The Penalty Effect and the Charitable Deduction: Significance and Sufficiency of an Alternate Channel}

Another strand of concern identified by Justice Douglas, this time through his concurring opinion in Cammarano, is whether a rule might operate, irrespective of its purpose, to penalize speech. ${ }^{245}$ Recall that Cammarano concerned the constitutionality of denying a business expense deduction for lobbying. Justice Douglas said that, for him, Cammarano would be a different case if the result of a taxpayer's lobbying was that the taxpayer lost all deductions for ordinary and necessary business expenses. ${ }^{246}$ This would be to "plac[e] a penalty on the exercise of First Amendment rights," which

242357 U.S. at 535 (Douglas, J., concurring) (citing Alexander Hamilton and the role loyalty oaths played in sparking Revolution).

${ }^{243} I d$.

${ }^{244}$ See supra notes 25-26 and accompanying text.

${ }^{245}$ Cammarano v. United States, 358 U.S. 498, 515 (1958) (Douglas, J., concurring).

${ }^{246} \mathrm{Id}$. 
he said "was in substance what [California] did in Speiser."247 Although to a certain extent, the question of whether a rule has a punitive purpose or a penalty effect may overlap, a rule could be enacted with innocent intentions but punitive results and perhaps be unconstitutional on that basis alone. Accordingly, the Political Activities Prohibition should be analyzed from the perspective of a penalty effect.

The penalty effect could be an issue for purposes of tax exemption under section 501(c)(3) because the "taxpayer," i.e., the organization, loses the entire benefit of exemption even for minor or insubstantial violations. ${ }^{248}$ This aspect of the political activity and lobbying rules ${ }^{249}$ has led some commentators to conclude that, either as a matter of policy or as a matter of constitutional necessity, the lobbying and political activity rules should be changed. ${ }^{250}$ As Justice Douglas argued, if the Political Activities Prohibition serves as a penalty for speech, then it may fit the Speiser model. ${ }^{251}$ To put a label on the argument, the Rule would be an unconstitutional condition of taxexempt status.

One answer to this concern has been through the alternate channel analysis, ${ }^{252}$ namely that the penalty effect is avoided because of the availability of an alternate channel for speech. This was the argument made by Justice Blackmun's concurrence and to a lesser extent the majority in $T W R \cdot{ }^{253}$ But $T W R$ concerned the lobbying limit of section

${ }^{247} \mathrm{Id}$. Of course, the penalty effect (losing all business deductions) was not an issue in Cammarano because the disallowance rule affected only lobbying expenses and not other trade or business expenses. $I d$.

${ }^{248}$ See supra note 84 and accompanying text (discussing the argument that the IRS should allow charities greater leeway when enforcing the Political Activities Prohibition).

${ }^{249}$ There is more flexibility in the lobbying context. See Charles E. Hodges II \& Edward M. Manigault, Political Activity and Lobbying by Charities: How Far Can it Go? What are the Risks?, 93 J. TAX'N 177, 179 (2000) (“Unlike the absolute prohibition on political intervention, a charity may, to a certain extent, be involved in activities intended to influence legislation."). Organizations (other than churches) can opt-out of the facts and circumstances "no substantial part" test and make an election under section 501(h), which offers more precision on the amount of lobbying allowed and on the sanction. Id. at 180. As discussed above, the penalty for any political activity formally is loss of exemption, though the IRS exercises considerable discretion in this regard.

${ }^{250}$ See Chisolm, supra note 30, at 362-63 (proposing more carefully tailored rules about the prohibition on campaign intervention for charitable organizations); Benjamin M. Leff, "Sit Down and Count the Cost": A Framework for Constitutionally Enforcing the 501(c)(3) Campaign Intervention Ban, 28 VA. TAX REV. 673, 677-79 (2009) (arguing that the Political Activities Prohibition for charitable organizations is likely unconstitutional and proposing an enforcement paradigm).

${ }^{251}$ Cammarano, 358 U.S. at 515 (Douglas, J., concurring).

${ }^{252}$ See supra Part II.D for a discussion of the alternate channel analysis. Another answer to the question of the penalty effect may simply be one of judgment. The purpose of the law to define charity and the tax context for the law may alone be sufficient to conclude that alternate channel or not, there is no penalty effect involved.

${ }^{253}$ See supra notes 177-79 and accompanying text (discussing the TWR opinions). 
501(c)(3), and as commentators have noted, in general, the alternate channel available for lobbying is more permissive than the alternate channel available for political activity. ${ }^{254}$ Nevertheless, the D.C. Circuit in Branch Ministries v. Rossotti, upheld the constitutionality of the Political Activities Prohibition by invoking affiliations of section 501(c)(3), section 501(c)(4), and section 527 organizations as a sufficient alternate channel. ${ }^{255}$

Accordingly, assuming that an alternate channel is still useful for constitutional purposes, ${ }^{256}$ the question is the sufficiency of the alternate channel upheld in Branch Ministries. The general criticism would be that the multi-step structure of Branch Ministries (three entities instead of two $)^{257}$ is a burden or dilutes the speech. Arguably, because the Court has approved a separate entity alternate channel approach before and there is no contrary authority, the addition of the section 527 layer is not a constitutional impediment. ${ }^{258}$ Notwithstanding the Court's statements in Citizens United regarding the burden of establishing a PAC, ${ }^{259}$ as argued above, the tax context here should be distinguishable. ${ }^{260}$

In addition, to the extent that more or different channels are needed, a reviewing court should consider the option of an alternate channel through an affiliated for-profit corporation. Commentators-

${ }^{254}$ See Chisolm, supra note 30, at 325 (noting that charitable organizations "may establish and control a sister organization under section 501(c)(4), which imposes no restrictions on lobbying"). This is because unlimited lobbying may be conducted through an affiliated section 501(c)(4) organization, but not unlimited political activity because section 501(c)(4) organizations may not allow political activity to become a primary purpose. Treas. Reg. $\S$ 1.501(c)(4)-1(a)(2)(ii) (as amended in 1990).

255211 F.3d 137, 143 (D.C. Cir. 2000).

${ }^{256}$ As noted above, the Court disapproved of the PAC alternate channel for corporate independent expenditures in Citizens United. But the Court's derogation in Citizens United of the PAC alternate channel should be seen in the context of the Court's concern about the Electioneering Rule as a ban on corporate speech. See supra Part II.D. The Political Activities Prohibition is not such a ban.

257211 F.3d at 143. burden).

${ }^{258}$ See Galston, supra note 12, at 911 (concluding that such a structure does not impose a

${ }^{259}$ Citizens United v. FEC, 130 S. Ct. 876, 897 (2010) ("PACs are burdensome alternatives; they are expensive to administer and subject to extensive regulations").

${ }^{260}$ Discussion about the presence or absence of alternate channels emphasizes again the usefulness of viewing the statutory scheme of the exemption provisions as a whole-as a network. See Galston, supra note 181, at 103 (discussing, throughout the article, a "network" approach to political activity by tax-exempt organizations). This provides a way of accommodating organization-level speech among different tax categories. See supra text accompanying note 183 . If the default position is free speech and a taxable organization, then, when the organization utilizes the exemption system, both positions change at the choice of the organization. The organization is tax-exempt and the ability to speak as a for-profit entity may be affected. The different exemption categories and ability to own for-profit and nonprofit affiliates are boxes for how to treat different activities of the same, albeit formally separate, organization for tax purposes. 
and the Court in $T W R$ - have focused on tax-exempt affiliates because this was the structure used in $T W R$, and is the one most commonly employed. But if speech is the concern, the for-profit alternate channel generally is available. ${ }^{261}$

One objection might be that a section 501(c)(3) organization does not have the option of establishing a for-profit affiliate to engage in political activity for the same reason that a section 501(c)(3) organization may not directly set up a section 527 organization. ${ }^{262}$ The barrier here is the legislative history to the 1974 section 527 legislation, which said that a section 501(c)(3) organization may not have an affiliated political organization. ${ }^{263}$ If the Court did decide, however, to rest the decision on an alternate channel, one avenue might be to mandate a simplified structure, for example, free the IRS from the 1974 legislative history and specifically allow the affiliation. ${ }^{264}$

Thus, up to this point, there are plausible arguments for concluding that the Political Activities Prohibition does not have a penalty effect. However, one overlooked aspect of the alternate channel that was cited with approval in TWR may also be relevant; namely, that use of an affiliated section 501(c)(4) organization does not in fact allow for unfettered speech ${ }^{265}$ This is because unlimited lobbying activity by a section 501(c)(4) organization is permitted only if the lobbying activity is related to the organization's social welfare purpose. ${ }^{266}$ But unrelated lobbying activity, if it is a substantial purpose of the organization, does result in loss of section 501(c)(4) status. ${ }^{267}$

${ }^{261}$ Indeed, the Code explicitly contemplates tax-exempt organizations owning for profit organizations and provides for the appropriate tax treatment. See I.R.C. § 512(b)(13) (2006) (providing special rules for amounts received from controlled entities).

${ }^{262}$ There is an exception for activity related to affecting a judicial nomination. See supra note 139 .

${ }^{263}$ S. Rep. No. 93-1357, at 30 (1974) (noting that section 527 was "not intended to affect in any way the prohibition against certain exempt organizations (e.g., section 501(c)(3)) engaging in "electioneering"').

${ }^{264}$ Nothing statutorily appears to prevent the IRS from allowing such a structure, but nonetheless, with legislative history to the contrary, the IRS is unlikely to change current practice without clear direction from a higher authority.

${ }^{265}$ Regan v. Taxation with Representation of Wash., 561 U.S. 540, 543 (1983) (emphasis added) ("Section 501(c)(4) organizations ... are permitted to engage in substantial lobbying to advance their exempt purposes.").

${ }^{266}$ I.R.C. § 501(c)(4) (2006) (“[O]rganizations not organized for profit but operated exclusively for the promotion of social welfare ... and the net earnings of which are devoted exclusively to charitable, educational, or recreational purposes.").

${ }^{267}$ See Rev. Rul. 2004-6, 2004-1 C.B. 328 ("Organizations that are exempt from federal income tax under $\S 501$ (a) as organizations described in $\S 501(\mathrm{c})(4) \ldots$ may, consistent with their exempt purpose, publicly advocate positions on public policy issues.”); Rev. Rul. 81-95, 1981-1 C.B. 332 ("Thus, an organization may carry on lawful political activities and remain exempt under section 501(c)(4) as long as it is primarily engaged in activities that promote social welfare."). 
Accordingly, the section 501(c)(3) organization's section 501(c)(4) alternate channel is an unrestricted alternate only to the extent of the relatedness of the lobbying to the exempt purpose of the organization. ${ }^{268}$

There is no indication that this issue was directly considered by the Court in TWR. The question then is whether the First Amendment in the tax-exempt organization context is concerned with a relatedunrelated distinction or, instead, is concerned with speech as speech, related or not. If a related-unrelated distinction has significance for the First Amendment, then consistent with the TWR alternate channel (which protected only related lobbying), a sufficient alternate channel for political activities need be only for related political activity. ${ }^{269}$ If, however, the First Amendment does not take into account tax concerns, then assuming that an alternate structure is constitutionally significant, one issue relevant for both the lobbying limitation and the Political Activities Prohibition, is the extent to which an unrestricted outlet for the speech-related or not-is required. If the use of affiliates - exempt or for-profit - is held to be an insufficient alternate channel, then any limitation-related or unrelated - on lobbying or political activity is jeopardized.

This raises yet another major challenge to the tax exemption system potentially presented by Citizens United: the extent to which any limitations on speech are permitted in connection with the tax exemption of any exempt organization. This is because the entire classification of an organization as exempt is to a certain extent based upon the power of Congress to delineate a purpose and promote or classify it exclusive to other things. If Congress does not have the power to limit speech in relation to a tax classification, then the constitutionality of many other tax classifications also are likely to come into question.

In any event, even if the Court decided that a sufficient alternate channel was constitutionally necessary, that the currently available channels are insufficient, and as a result, held that the Political

${ }^{268}$ This presents an interesting issue with respect to the lobbying limitation, which may turn out to be more restrictive from a speech perspective than the Political Activities Prohibition. This is because there is no outlet for unlimited, unrelated lobbying activity by an exempt organization. By contrast, there potentially is such an outlet for political activity through use of a section 527 political organization. The political organization option is not available for unlimited lobbying, however, because lobbying is not considered an exempt purpose under section 527. I.R.C. $§ 527(\mathrm{e})(2)$ (2006) (defining "exempt function" as "the function of influencing or attempting to influence the selection, nomination, election, or appointment of any individual to any Federal, State, or local public office ... or the election of Presidential or VicePresidential electors").

${ }^{269}$ As discussed in Part IV, infra, however, the related-unrelated distinction itself is problematic in the political activity context. 
Activities Prohibition is unconstitutional, not much need change. Section 501(c)(3) would be rewritten to omit the prohibition, but conditioning a charitable deduction on a recipient's abstention from political activity would not necessarily be affected. ${ }^{270}$

And this leads to another seemingly unremarked aspect of the alternate channel analysis: it only affects exemption. It says nothing about deductions. Indeed, implicit in Justice Blackmun's approval of the section 501(c)(4) alternate channel is affirmation of Cammarano as applied to section 170 of the Code. ${ }^{271}$ To see this, note that Justice Blackmun's alternate channel only preserves tax-exemption for the organization (through use of an affiliate). Lost, however, is the ability to receive tax deductible contributions, at least with respect to the organization's lobbying activity. ${ }^{272}$ In other words, the alternate channel results in a loss of an indirect tax benefit; yet this was not of concern to Justice Blackmun or to the Court - the challenge, and their focus, was on the exemption condition.

Shifting then to deductions and section 170 of the Code, the need for an alternate channel for the organization's speech does not factor into whether the political activity and lobbying limitations of section 170 are constitutional. This is because denying an individual or entity's deduction for a contribution to an organization that engages in political or lobbying activity has only an indirect effect on the speech, at best. Such a rule does not affect the speech of the individual or entity as such. It does not even affect the ability of individuals to associate and speak collectively (which they remain free to do). Rather, as the Court has said, such a rule merely reflects Congress's decision not to subsidize the speech. ${ }^{273}$ In this regard, it is

${ }^{270}$ As currently written, a charitable contribution does not exist for contributions to an organization that is "disqualified for tax exemption under section 501(c)(3) by reason of attempting to influence legislation, and which does not participate in, or intervene in ... any political campaign ...." I.R.C. $\S 170(c)(2)(D)$. Accordingly, if the Political Activities Prohibition of section 501(c)(3) were held unconstitutional, section 170(c)(2)(D) on its face would be to no effect as a technical matter. But even if courts did not read into section 170 a no political activity requirement, section 170 could easily be redrafted to deny a charitable deduction for contributions to organizations that engage in political activity or substantial lobbying.

${ }^{271}$ Regan v. Taxation With Representation, 461 U.S. 540, 553 (1983) (Blackmun, J., concurring) ("A $\S 501(\mathrm{c})(3)$ organization's right to speak is not infringed, because it is free to make known its views on legislation through its $\S 501(\mathrm{c})(4)$ affiliate without losing tax benefits for its nonlobbying activities."').

${ }^{272}$ See id. ("The $\$ 501(\mathrm{c})(4)$ affiliate would not be eligible to receive tax-deductible contributions.").

${ }^{273}$ Cammarano v. United States, 358 U.S. 498, 513 (1959) (finding that Congress's refusal to allow deductions for political activity "express[es] a determination ... that since purchased publicity can influence the fate of legislation which will affect, directly or indirectly, all in the community, everyone in the community should stand on the same footing as regards its purchase so far as the Treasury of the United States is concerned"). 
noteworthy that the speech at issue in Cammarano involved the most sympathetic type of lobbying expense - self-defense lobbying. ${ }^{274}$ Yet the Court had no sympathy. ${ }^{275}$

Further, the penalty effect does not appear to be an issue for the charitable contribution deduction under section 170. If a taxpayer makes a contribution to a charity that impermissibly lobbies or engages in political activity, the taxpayer's ability to take a charitable contribution deduction as a general matter is not affected. Thus, the taxpayer is not penalized in the broad sense that concerned Justice Douglas.

In short, although it may be that the section 170 limitations were enacted as a backstop to the section 501(c)(3) limits, ${ }^{276}$ they nonetheless would require a distinct constitutional challenge to invalidate. ${ }^{277}$ Without such a successful challenge to the section 170 limitations, removal of the section 501(c)(3) limits may not change much, at least with respect to organizations that want to be eligible to receive tax deductible contributions. ${ }^{278}$ Such organizations would continue to abide by the prohibition.

\section{Implications of Reliance on Constitutional Conditions Analysis.}

So far, the analysis has not directly discussed the doctrine of constitutional conditions, lamented by commentators for its incoherence. ${ }^{279}$ Under this doctrine, a condition made in connection

${ }^{274}$ Petitioners were owners of wholesale alcohol businesses. One was lobbying against a bill in the State of Washington that would give the state complete control over wholesale alcohol sales. The other was lobbying against a statewide prohibition bill in Arkansas. Id. at $500-02$.

275 See id. at 513 (affirming the lower court's ruling against both petitioners).

276 See supra note 64 and accompanying text.

${ }^{277}$ A similar analysis also should be made with respect to eligibility to receive tax-exempt bond financing under section 145 of the Code. Like the charitable deduction, the tax benefit is not provided directly to the section 501(c)(3) organization. Rather, the purchaser of the bonds receives the benefit of tax-exempt interest. I.R.C. $\S 145$ (2006). For section 501(c)(3) organizations that rely on the availability of tax-exempt financing, such as charitable hospitals, a Political Activities Prohibition could be made a condition on receipt of such financing irrespective of whether such a prohibition is retained as a condition of tax exemption. In other words, for purposes of the Political Activities Prohibition, each of the tax benefits currently associated with tax-exempt status should be analyzed distinctly. For an argument that the tax benefits currently associated with section 501(c)(3) status should be disaggregated, see Colinvaux, supra note 100 , at 64 .

278 Professors Crimm and Winer advocate removal of the Political Activities Prohibition as an exemption condition but retaining it for charitable deduction purposes. They note that this might not have a significant impact on houses of worship, many of which rely on contributions from individuals who do not itemize deductions and so who do not claim a deduction in any event. See CRIMM \& WINER, supra note 27, at 327. Crimm and Winer also note that the impact on other section 501(c)(3) organizations is "less clear." Id.

279 The confusion surrounding the constitutional conditions doctrine stems from the inscrutable framework for decision and inconsistent application by the courts. See e.g., Richard 
with providing a government benefit may be unconstitutional even if the government is under no obligation to provide the benefit. ${ }^{280}$ The central concern is that if the government is prohibited from directly limiting a person's rights, then the government should not be able to so limit a person's rights through the imposition of a condition in connection with a benefit. Speiser, Cammarano, and TWR are often cited as "constitutional conditions" cases. ${ }^{281}$ Importantly, TWR, and its alternate channel analysis have been cited approvingly in other constitutional conditions cases, such as Rust v. Sullivan ${ }^{282}$ and FCC v. League of Women Voters of California. ${ }^{283}$ Accordingly, the Court's analysis of alternate channels in Rust and League of Women Voters ${ }^{284}$ is commonly cited in scholarship in connection with the Political Activities Prohibition because of their relevance to the alternate channel analysis. ${ }^{285}$

However, the cases have been grouped together by courts not only because of alternate channel but also because each case involves the

Epstein, Forward: Unconstitutional Conditions, State Power, and the Limits of Consent, 102 HARV. L. REV. 4 (1988); Kathleen Sullivan, Unconstitutional Conditions, 102 HARV. L. REV. 1413 (1989).

${ }^{280}$ As outlined by Professor Chisolm, a government decision not to subsidize speech is, everyone agrees, fine. But if the government provides a benefit, and the grant or denial of the benefit is based on viewpoint or the content of speech or on suspect classifications, then the condition is reviewed subject to strict scrutiny and a compelling state interest is required. However, if the grant or denial of the benefit is just "a simple policy of nonsubsidy," then only rational basis review is required. Simon, Dale \& Chisolm, supra note 27. TWR equated tax exemption with a subsidy, said that Congress had merely decided not to subsidize lobbying, and then appears to have applied a rational basis review. In the context of political activities, Professor Chisolm, writing however before the Branch Ministries decision, argued that the penalty effect mooted by Justice Douglas in Cammarano, should trigger a heightened scrutiny because of the absence of a sufficient alternate channel for political activities.

${ }^{281}$ In Speiser, the Court held that the loyalty oath was an unconstitutional condition for the reasons stated supra. In Cammarano and $T W R$, the Court held that the conditions were constitutional.

282500 U.S. 173 (1991).

283468 U.S. 364, 400 (1984). Here, the Court struck down a federal law that provided funding to noncommercial television and radio stations on the condition that such stations not engage in editorializing. Central to the Court's reasoning was that the law did not allow for the editorializing activity even through a separate affiliate. The Court cited the TWR alternate channel approvingly, stating that if the stations were permitted to "establish 'affiliate' organizations which could then use the station's facilities to editorialize with nonfederal funds, such a statutory mechanism would plainly be valid".

${ }^{284}$ Both cases stand for the general proposition that an alternate channel is relevant, and so both offer some support for the political activities prohibition to the extent that its alternate channel is sufficient. On the one hand, Rust could be distinguished because the alternate channel in Rust arguably is "better" than that provided by the tax rules because in Rust no separate organization was required; rather, the separation could occur within the existing organization. On the other hand, League of Women Voters provides support for the separate affiliation option. ${ }^{285}$ Galston, supra note 181; Leff, supra note 250; Simon, Dale \& Chisolm, supra note 27. 
provision of a government benefit. ${ }^{286}$ In Rust and League of Women Voters, the benefits are direct public funding. ${ }^{287}$ In TWR, the benefits cited are the subsidy-like exemptions and deductions. ${ }^{288}$ Importantly, under a constitutional conditions analysis, from the provision of a "benefit" comes a facilitation of government conditions that may directly affect fundamental rights. Thus, in Rust, the Court upheld a condition on the funding of family planning services under Title $\mathrm{X}$ of the Public Health Service Act, namely that no abortion counseling be provided with the federal funds. ${ }^{289}$ The Court noted that the funding scheme distinguished between a project "grantee" and the funded project of the grantee (a "Title X Project"), and that grantee as grantee remained free to provide such counseling, just not in connection with the separately established, federally funded project. ${ }^{290}$ Thus, the abortion-related condition did not burden the grantee's First Amendment rights to speak. ${ }^{291}$

This sort of micromanaging may be permissible in the context of direct public funding. The question is the extent to which it is permitted in the context of government benefits to charitable organizations. Reliance on Rust to uphold the Political Activities Prohibition could run the risk of turning the "independent" sector into a series of "Project Xs," subject to explicit direction by the federal government. In other words, if Rust applies conceptually, then the door may be open to conditioning any number of restraints on charitable organizations without constitutional impediment.

${ }^{286}$ The Court called Rust v. Sullivan "a case of the Government refusing to fund activities, including speech, which are specifically excluded from the scope of the project funded." 500 U.S. at 194-195. The Rust Court cited a case in which the Court upheld a state's decision to subsidize childbirth services but not abortion, providing that the government may "'make a value judgment favoring childbirth over abortion, and ... implement that judgment by the allocation of public funds." Id. at 192-193 (quoting Maher v. Roe, 432 U.S. 464, 474 (1977)). The Court then cited TWR for the proposition that the "legislature's decision not to subsidize the exercise of a fundamental right does not infringe the right." Id. at 193 (quoting Regan v. Taxation with Representation of Wash., 461 U.S. 540, 549 (1983)) (internal quotation marks omitted).

${ }^{287}$ See Rust, 500 U.S. at 203 (prohibiting recipients of family planning funds under Title X from engaging in abortion counseling); League of Women Voters of Cal., 468 U.S. at 402 (finding a ban on editorializing by an educational broadcasting station that received direct public funding violated the First Amendment).

288 See Regan v. Taxation With Representation, 461 U.S. 540, 549 (1983) (noting that "appropriations are comparable to tax exemptions and deductions").

289500 U.S. at 203.

${ }^{290} \mathrm{Id}$. at 196 (noting that preventing an organization that receives funding under Title $\mathrm{X}$ from counseling about abortion " $\mathrm{do}[\mathrm{es}]$ not force the Title $\mathrm{X}$ grantee to give up abortion-related speech; [it] merely require[s] that the grantee keep such activities separate and distinct from Title X activities").

${ }^{291} \mathrm{Id}$. at 203 . 
This risk is present because $T W R$ characterizes tax exemption as a subsidy - thus inviting a constitutional conditions analysis. ${ }^{292}$ But the subsidy characterization is not necessarily accurate. Whether section 501(c)(3) provides a subsidy may depend upon the rationale for charitable tax exemption. ${ }^{293}$ To the extent that section 501(c)(3) is designed to provide a cash grant to the organization in the amount of income tax the organization would otherwise owe, per $T W R$, then perhaps there is a subsidy.

But this question has been debated since the outset of the exemption in 1913. If charitable exemption is recognition of a cosovereign, then exemption makes sense but not as a "subsidy." charitable exemption is to lessen the burdens of government, ${ }^{295}$ then it is less of a subsidy than a division of labor. If charitable exemption reflects a normative principle that "good" organizations simply should not be taxed, perhaps exemption is not a subsidy in the traditional sense of the term. Rather, the exemption just recognizes that charitable organizations should, as a matter of tax policy, be taxed differently from for-profit organizations. Further, even if there is a subsidy conceptually, for many if not most charitable organizations, tax-exempt status does not provide much if any actual tax savings. And it would therefore be ironic to base the constitutionality of onerous conditions on the provision of a subsidy that is actually of little monetary value. Here again, however, section 501(c)(3) and section 170 are distinct. Although some have argued that section 170 is not a subsidy, ${ }^{296}$ the more common approach is the

${ }^{292}$ See TWR, 461 U.S. at 544 ("Both tax exemptions and tax deductibility are a form of subsidy that is administered through the tax system.").

${ }^{293}$ See, e.g., Daniel Halperin, Is Income Tax Exemption for Charities a Subsidy?, 64 TAX L. REV. 283, 283-84 (2011) (discussing "whether the income tax exemption for charities is consistent with normal income tax principles or is a departure that must be justified as a subsidy").

${ }^{294}$ See Brody, supra note 126, at 592 (footnote omitted) ("While most observers have described tax exemption as a subsidy, a zero rate of tax differs qualitatively, not just quantitatively, from a one-percent rate of tax.").

${ }^{295}$ See, e.g., H.R. REP. No. 75-1860, at 19 (1938) ("The exemption from taxation of money or property devoted to charitable and other purposes is based upon the theory that the Government is compensated for the loss of revenue by its relief from financial burden which would otherwise have to be met by appropriations from public funds, and by the benefits resulting from the promotion of the general welfare.").

${ }^{296}$ See, e.g., William D. Andrews, Personal Deductions in an Ideal Income Tax, 86 HARV. L. REV. 309, 313 (1972) (discussing the charitable tax deduction in terms of a consumption tax). 
subsidy view. $^{297}$ Indeed, unlike tax exemption, the charitable deduction has long been considered a "tax expenditure." 298

The discussion above has several implications. Notwithstanding $T W R$, the constitutional conditions doctrine's applicability to charitable tax exemption because it is a government-provided subsidy is not self-evident. At a minimum, assuming that the government is providing a "benefit," it is important to maintain distinctions between the benefit of tax exemption and the benefit of direct subsidies such as those provided in Rust and League of Women Voters. Although the cases commonly are grouped together, the difference with respect to the benefits provided suggests that as a general matter a different analysis of the condition should apply.

But if the constitutional conditions doctrine applies with less force to tax-exemption, or arguably does not apply at all, what is the effect on the analysis of the constitutionality of the Political Activities Prohibition? On the one hand, if exemption is not a benefit, this undermines the argument made in Part II.E that the Rule is not identity based speech because it makes section 501(c)(3) status less like a tax classification (i.e., an invention of the tax code) and more like a core entity type, akin to a corporation. Thus, following the reasoning of Citizens United, the Political Activities Prohibition is more like a ban on corporate speech than was argued earlier. On the other hand, even if charitable tax exemption is not a government "benefit," it can still be upheld for all the reasons stated previouslythe Rule's purpose is not to suppress speech and Congress has a sufficient interest in having a nonpartisan charitable sector. Perhaps most importantly, however, the question of whether section 501(c)(3) provides a "benefit" highlights again the distinction between sections 501(c)(3) and 170. So even if the question casts additional doubt on the constitutionality of the Political Activities Prohibition for exemption purposes, it says nothing about the constitutionality of the prohibition for deduction purposes. And, to a certain extent, it is really section 170 that is the more important of the two. ${ }^{299}$ Congress

${ }^{297}$ See, e.g., Miranda Perry Fleischer, Theorizing the Charitable Tax Subsidies: The Role of Distributive Justice, 87 WASH. U. L. REV. 505, 517 (2010) (discussing the subsidy theory and noting that it is the more "common" view); Simon, Dale \& Chisolm, supra note 27, at 274-75 (discussing the various subsidy theories of federal taxation).

${ }^{298}$ The five-year (2008-2012) tax expenditure for the charitable tax deduction is estimated to be $\$ 264$ billion. See Staff OF JOINT Comm. On TAXation, Estimates of Federal TaX EXPENDITURES FOR FISCAL YeARS 2008-2012, at 53, 55-56 (Comm. Print 2008) (combining $\$ 35.9$ billion for education, \$204.9 billion for social services, and \$23.2 billion for health).

${ }^{299}$ Again, it is important to keep in mind the several benefits associated with section 501(c)(3) status, and the varying importance of one or the other to a particular organization. For some organizations, exemption might be of great significance. For others, it might be the deduction. For still others, it might be the ability to benefit from tax-exempt financing. To 
has a stronger spending purpose and the tax benefit arguably is more significant to the charities (even though less direct).

\section{Summary}

In brief, this Part has argued that even if the Court was persuaded that the purpose of the Political Activities Prohibition was to suppress speech or that the prohibition had a penalty effect, and therefore concluded that the prohibition was unconstitutional, present law would not change significantly. The disallowance of the charitable deduction for contributions to organizations that engage in political activity requires a distinct constitutional challenge, which it should easily survive. In addition, the charitable sector should be mindful of the perils of relying on a constitutional conditions analysis in support of the Political Activities Prohibition. That analysis could open the door to increased government involvement in the affairs of charitable organizations.

\section{Alternatives to the StATUS QUO ARE WANTING}

So far, the analysis has focused largely on whether the Political Activities Prohibition is constitutional as such without much comment on alternatives. What if, notwithstanding the arguments made in Part II of this Article, the Court concluded that the prohibition was an unconstitutional burden on speech? What would this mean? Such a conclusion would raise a number of difficult questions. Must the law allow unlimited political activity by charities? May a political purpose be a charitable purpose? Are political activities to be considered as an acceptable means to a (nonpolitical) charitable end? Are limits to the political activity of charities permissible, and if so, what kind of limits? These are key questions that should inform not only the constitutional analysis, but also, assuming the constitutionality of the Political Activities Prohibition, whether Congress should, on its own initiative, modify it.

\section{A. One Extreme: Congress May Not Restrict the Political Activity of Charitable Organizations}

At first blush, it might be assumed that if the Political Activities Prohibition is unconstitutional, then no limit or restraint upon the

undertake a detailed analysis of each is beyond the scope of this Article. The point here is to highlight that answering the question of the prohibition with respect to one benefit - that of exemption - does not answer the question with respect to other benefits. 
political activities of charities is allowed. Such a conclusion certainly would be the easiest to administer and enforce, as there would be nothing to administer or enforce. The line between political and nonpolitical activity, between education and propaganda, would not have to be drawn. There would be no facts and circumstances to consider.

Such a conclusion also would best facilitate core First Amendment speech. Facing no restraint, charities could speak and spend on political activity as much as desired. To the extent that protecting speech is the critical concern, discarding the prohibition and replacing it with unfettered speech seems an easy and intuitively attractive solution. ${ }^{300}$ But this overlooks a critical point, namely that unless there is some limit on the political activity of section 501(c)(3) organizations, the charitable purpose requirement ${ }^{301}$ would lose much of its meaning. Currently, it is because of the Political Activities Prohibition that a section 501(c)(3) organization as such stands apart, or operates distinctly, from its actual or contemplated political activity. That is, because a section 501(c)(3) organization is prohibited from participating in politics, by definition there must be a meaningful "charity" in existence apart from any political activity. It is from this vantage point that we often think of the merits of the Political Activities Prohibition: i.e., whether a charity, viewed separately from any political activity, may or should be able to engage in politics.

But, without the Political Activities Prohibition or any limit on political activities, this vital distinction would erode. There would be nothing to prevent an organization formed to "help feed the poor" from doing nothing other than campaign intervention.

Because the charitable purpose requirement has no substantive or positive content $^{302}$-it is after all a purpose requirement-an organization with the purpose of helping to feed the poor should qualify under the organizational and operational test even if all its activities were political. Clearly, the organizational test would be no barrier, as helping to feed the poor is a charitable purpose. ${ }^{303}$ The

${ }^{300}$ If such an approach were adopted, it would call into question limitations on the political activities of other exempt organizations and the constitutionality of the tax under section 527(f)(1), which provides that an exempt organization, which is not a political organization, must include certain amounts in gross income. I.R.C. § 527(f)(1) (2006).

${ }^{301}$ Again, "charitable" here includes all the section 501(c)(3) exempt purposes: charitable, educational, religious, scientific, etc. I.R.C. $\$ 503(\mathrm{c})$.

${ }^{302}$ See Colinvaux, supra note 100, at 14-15 (discussing the absence of positive requirements for charitable status).

${ }^{303}$ The organizational test requires that the organization be organized exclusively for exempt purposes. Treas. Reg. $\S 1.501(c)(3)-1(b)$ (as amended in 2008). Typically it may be 
operational test too would be satisfied. Here, the regulations say that to be operated exclusively for exempt purposes, the primary purpose of the organization must be an exempt purpose. This primary purpose test is met "if [the organization] engages primarily in activities which accomplish" the exempt purpose. ${ }^{304}$ Under this formulation, activities themselves are not necessarily either charitable or uncharitable, but are viewed in connection with the ends served. Accordingly, an organization that favored candidates who want to help "feed the poor" would be engaged in an activity to accomplish exempt purposes.

In short, without any restriction on political activities, it is not clear whether anything would prevent a purely political organization from qualifying as a section 501(c)(3) organization. The term "PAC" would have to be modified to include not only "political action committee" but also "political action charity." In addition to all the other types of present law charities (hospital, college or university, church, scientific organization, etc.) a charity could also be an action organization, ${ }^{305}$ or what we think of today as a political organization.

\section{B. Assuming Change to the Prohibition, Some Limit Should Be Contemplated}

If equating a political organization and a charity is unpalatable, one might want to consider various limitations. One approach, based on the current way of thinking about charity, might be to allow political activities but only for "real" charities, that is, charities that have some quantum of charitable activity that is not political activity. As a general matter, however, this would not work because our system provides exemption based on purposes not activities. ${ }^{306}$ If the purpose is legitimate and the activities plausibly are undertaken to advance the purpose, the discussion ends. There is no inquiry into whether an activity is charitable as such. ${ }^{307}$

satisfied through a statement in the organization's governing instrument. Id. In general, "feeding the poor" would qualify as a charitable purpose under the Treasury regulations. See Treas. Reg. $\S 1.501(\mathrm{c})(3)-1(\mathrm{~d})(2)$ (defining charitable to include "[r]elief of the poor and distressed or of the underprivileged").

304 Treas. Reg. $\$ 1.501(\mathrm{c})(3)-1(\mathrm{c})(1)$.

${ }^{305}$ Note that because of the Political Activities Prohibition, the Treasury Regulations provide that a section 501(c)(3) organization may not be an action organization. Treas. Reg. $\S$ 1.501(c)(3)-1(c)(3)(i). An action organization includes an organization that engages in political activity. Treas. Reg. $\$ 1.501(\mathrm{c})(3)-1(\mathrm{c})(3)(\mathrm{ii})$.

${ }^{306}$ Hopkins, supra note 25, at 72 ("The primary purpose test looks . . . to an organization's purpose rather than its activities.").

${ }^{307}$ Activities are, however, relevant. See infra Part IV.C. If activities serve a non-charitable purpose, a substantial level of such activities may indicate that a primary purpose of the organization is not charitable, and therefore the organization ceases to qualify under section 
Nevertheless, one might require as an affirmative obligation of section 501(c)(3) status that an organization may not qualify unless it conducts some level of activity that serves an exempt purpose and that is not political activity. The obvious and difficult questions would be how much nonpolitical activity is required and how it would be measured. And any such requirement, though styled as an affirmative obligation to conduct nonpolitical activity, would in effect be a limit on the amount of political activity because inevitably, the requisite amount of "good" activity would be defined in relation to the political activity. ${ }^{308}$

Alternatively, one could attempt to draw a different line and say that charitable exemption should be denied to organizations that are really political organizations in disguise. Such an approach would be to assert that there is a relevant distinction between exempt purposes and political purposes, and that charitable exemption should be granted only for "exempt" nonpolitical purposes. The analysis here would not be on the political activities as such, but whether the activities "truly" further an exempt purpose, or instead a political purpose. This could be similar to the present law commerciality doctrine, which denies charitable exemption if the activities of an organization take on too much of a commercial hue, i.e., the organization seems more like a for profit business than a charity. ${ }^{309}$

But, as in the commerciality context, the line distinguishing a political purpose from an exempt purpose would likely be very difficult to draw, especially in an area protected by the First Amendment. For example, an organization could state its purpose as finding ways to help the poor. If the organization promotes the

501(c)(3). See Better Bus. Bureau of D.C., Inc. v. United States, 326 U.S. 279, 283 (1945) (stating that, for an educational non-profit organization, "the presence of a single noneducational purpose, if substantial in nature, will destroy the exemption regardless of the number or importance of truly educational purposes").

${ }^{308}$ For example, in order for such an affirmative requirement to have substance, the nonpolitical activity must be substantial, otherwise a token amount would do. See I.R.C. $\S$ 501(c)(3) (2006) ("no substantial part" of the activities of a 501(c)(3) organization may attempt "to influence legislation [or] ... participate in, or intervene in ... any political campaign on behalf of . . . any candidate for public office"). But substantiality likely would have meaning only in relation to the amount of political activity. An organization with little-to-no political activity would not have to undertake much nonpolitical activity to qualify. But an organization with considerable political activity would have a higher nonpolitical activity threshold. This in turn would encourage the organization to reduce the amount of political activity so as to strengthen the substantiality of the nonpolitical activity. Assuming that the Supreme Court holds the Political Activities Prohibition unconstitutional, all this raises the question of what sorts of limits would be constitutionally acceptable and the rationale.

${ }^{309}$ See generally John D. Colombo, Commercial Activity and Charitable Tax Exemption, 44 WM. \& MARY L. REV. 487 (2002) (analyzing the rules that dictate amount of commercial activity that a charity is allowed to engage in while retaining the charitable exemption). 
candidates it believes (or says it believes) are committed to that goal, a principled challenge to the organization as "politically motivated" would be very hard to establish (even if it were clear what being politically motivated means).

Another limit might be to suggest that although political activity should be permitted, it should be limited in extent. That is, if it is too difficult to question an organization's true purpose as political or not, the quantum of activities of the organization could be used as a proxy for the organization's purposes. Thus, an organization with a lot of political activity could be suspect because, one might argue, the more political activity there is, the more likely the organization is really a political organization and not a charity. ${ }^{310}$

But even if we knew how much political activity generally should be equated with political purposes (10 percent? 50 percent?), there appears to be no reason to assume that the amount of political activity as such would have any meaningful bearing on an organization's "true" purpose. ${ }^{311}$ One could answer that it does not matter, we just need to limit the amount of political activity as a prophylactic against

${ }^{310}$ An activity-based limit would likely take one of two forms: something similar to the current "no substantial part" rule that applies in the lobbying context, I.R.C. § 501(h) (2006), or something like the rule in the section 501(c)(4) context, namely that the political activities may not become so extensive as to become a primary purpose of the organization, Treas. Reg. $\S$ 1.501(c)(4)-1(a)(2)(ii) (as amended in 1990); Rev. Rul. 81-95, 1981-1 C.B. 332 ("Thus, an organization may carry on lawful political activities and remain exempt under section 501(c)(4) as long as it is primarily engaged in activities that promote social welfare."). A "no substantial part" rule seems especially problematic, assuming that the Political Activities Prohibition is unconstitutional. If it is unconstitutional to bar political activities altogether because the speech is so fundamental, it may not make much sense to say that political activities are constitutional so long as the organization stops speaking after the first paragraph. And irrespective of the constitutional question, a "no substantial part" approach would arguably be worse than the current rule. For example, at least the current rule provides clarity on the question of how much activity is permitted-zero. But a no substantial part rule would introduce new uncertainty on the amount of permitted activity and new complexity. If a regime similar to that of section 501(h) were adopted, for example, it would be unlikely to satisfy organizations making missionbased arguments for allowing political activity, and all the benefits of the current rule (a nonpartisan sector) would be lost, with little apparent gain. The section 501(c)(4) approach would provide a more generous limit on political activities (capped so as to prevent a political purpose from becoming a primary purpose) but also raises similar questions. See infra Part IV.C for a more detailed discussion of these questions.

${ }^{311}$ Indeed, many organizations, especially organizations that believe political activity is required by the organization's mission, would argue that political activity that is related to the mission clearly serves an exempt purpose and so should not be subject to an arbitrary limit that does not take the relatedness of the speech into account. See Elizabeth Kingsley \& John Pomeranz, A Crash at the Crossroads: Tax and Campaign Finance Laws Collide in Regulation of Political Activities of Tax-Exempt Organizations, 31 WM. Mitchell L. REV. 55, 90-91 (2004) (offering an example of the issues associated with a nonprofit organization attempting to advance its purpose through political methods). If it could be established that an organization's political activity served a private end and not a charitable one, then it is a different question. But no special rule would be needed for such a case because the private benefit doctrine already should prohibit exemption. 
the political organization masquerading as charity. But then we have not advanced very far from the Political Activities Prohibition in the first place, which, among other things, is such a prophylactic. ${ }^{312}$ Furthermore, if it is unconstitutional to prohibit political activities, why is it constitutional to allow just a little bit of such activities? This too seems to be a difficult question to answer.

Yet another approach could be to treat political activity much like any other, and subject it to a related-unrelated test. ${ }^{313}$ Activities are neither inherently charitable nor noncharitable - their character depends upon relatedness to an exempt purpose. ${ }^{314}$ Assuming that a political purpose is not an exempt purpose, then, under this approach, political activity must be examined to see whether it is related to an exempt purpose. If it is related, then the activity is unrestricted. If it is unrelated, then the activity is permitted, but may not become so substantial that the purpose served becomes a primary purpose. If this happens, then the charitable exemption is lost. ${ }^{315}$

The difficulties with this approach are similar to those discussed previously in this Part regarding other possible limitations. First, drawing a related-unrelated distinction would be extremely difficult. Except in egregious cases, an organization, including a charity PAC, should be able to trace political activity to some exempt purpose. Second, adopting the related-unrelated paradigm involves limiting political activities - namely, unrelated political activity may not become substantial. To the extent the First Amendment is concerned with protecting speech as speech, it would seem not to matter much whether the speech is "related" to an organization's exempt purpose. Rather the question is whether it is burdened.

In addition, although a related-unrelated distinction may have intuitive appeal because it is familiar, it may not make sense in the speech context. Viewed under the First Amendment, we are talking about the speech of a section 501(c)(3) organization as a section 501(c)(3) organization (a value the Court presumably would be protecting if it struck down the Political Activities Prohibition). Does the rule).

${ }^{312}$ See supra notes 96-102 and accompanying text (describing the prophylactic purpose of

${ }^{313}$ See supra notes 269-273 and accompanying text (discussing the related-unrelated distinction made by section 501(c)(4)); see also Rev. Rul. 81-95, 1981-1 C.B. 332 (finding that an organization's primary purpose must be related to promoting social welfare).

${ }^{314}$ See supra notes 269-273 and accompanying text (discussing the related-unrelated distinction made by section 501(c)(4)).

${ }^{315}$ See Better Bus. Bureau of D.C., Inc. v. United States, 326 U.S. 279, 283 (1945) (stating that, for an educational non-profit organization, "the presence of a single noneducational purpose, if substantial in nature, will destroy the exemption regardless of the number or importance of truly educational purposes"). 
it make sense to say that a charity speaking as a charity is somehow speaking in a way that is unrelated to itself? It would seem that the presumption must be that organizational speech is in the best interest of the organization, or at least is of the organization and so somehow related to its (primary) purposes. If the charity speaks as the agent for another, then there likely are private benefit problems, which are covered by the private benefit doctrine. ${ }^{316}$ But a charity speaking as a "person," expressing views on its own behalf, is not speaking in a related or unrelated fashion. Whatever the content-it is just speech, and by definition the speech of a charity, which would seem to take on an inherently "related" character. In short, a limit based on a related-unrelated distinction would likely be no limit at all.

\section{Taxing Speech: The Most Plausible Limitation}

It is because of the futility of the above limitations that one might resort to regulating the political speech of charities through the Code. Namely, if it is unconstitutional to prohibit charities from engaging in political activity, and no reasonable line can be drawn, then what remains is to allow political activity by charities, but tax it. Such a solution would really be a continuation of current law, but instead of revocation of section 501(c)(3) status for engaging in political activity, the sanction would be to tax the organization with respect to the political activity.

This solution ties into perhaps the most forceful objection to the Political Activities Prohibition - namely, the nature of the penalty for violation. As noted above, the argument is that revocation of section 501(c)(3) status is a penalty disproportionate to the offense. ${ }^{317}$ Thus, a narrower approach would be to provide for a tax based on the extent of political activity, and therefore allow a charity to retain section 501(c)(3) status. This approach has some appeal because it does not undermine the power of Congress to decide whether or not to subsidize speech. Rather, it merely says that the penalty of revocation of section 501(c)(3) status is an overbroad remedy.

Using the existing legal regime, the result generally would be to treat expenses for political activity by section 501(c)(3) organizations just like those of other tax-exempt organizations. A charity could either make its political activity expenses ${ }^{318}$ from a separate

${ }^{316}$ See supra note 95 (defining the private benefit doctrine).

${ }^{317}$ See supra Part III.B.

${ }^{318}$ Congress would have to fashion a definition of "political activity expenses." Under present law, there are multiple terms at play. A "political expenditure" is a defined term for section 501(c)(3) organizations and generally means expenses in violation of the Political Activities Prohibition. I.R.C. $\S 4955(d)(1)$ (2006). Such expenses are subject to an excise tax. 
segregated fund (or PAC) ${ }^{319}$ or forgo the PAC option, make the expenses directly, and be subject to tax on the expenses under section $527(f)(1) .{ }^{320}$ Under that approach, the independent expenditures of charities, for example, generally would be subject to tax. ${ }^{321}$

There are some pitfalls. Perhaps most importantly, the political activities of charities that did not have expenditures directly associated with the activity (such as endorsements, which may require little-to-no direct expenditure) generally would not be captured. This is important not only because such activities can be the most potent, but also because failure to capture them undermines the rationale for the taxing speech approach: although Congress may refuse to promote political activity, it just must not over-punish. Accordingly, fully capturing the value associated with all political activities is critical. But, even if complex special rules could be developed rationally to attribute some expenditure to each instance of political activity, ${ }^{322}$ a missing link is that tax-exemption as such supports the entire section 501(c)(3) organization. Presumably, the reason for allowing a section 501(c)(3) organization to speak politically without using an alternative structure would be that section 501(c)(3) provides a distinct and valuable voice. But the value of that voice is to a certain extent directly supported by the blanket section 501(c)(3) exemption,

I.R.C. § 4955(a)-(b). Alternatively, tax-exempt organizations that are not section 501(c)(3) organizations and so not subject to an excise tax on their "political expenditures" are subject to tax on expenses for an "exempt function" as that term is defined in section 527. I.R.C. $\S$ 527(e)(2). Confusingly, "exempt function" expenses are generally those made for political purposes, i.e., for the exempt function of a political organization governed by section 527. Id.

${ }^{319}$ Such a fund would be considered a political organization under section 527 and subject to those rules. I.R.C. $\$ 527(\mathrm{f})(3)$.

${ }^{320}$ Section 527(f)(1) provides that a tax-exempt organization (other than a section 527 political organization) is subject to tax on the amount of its political expenses or the amount of its investment income, whichever is less. I.R.C. $\$ 527(\mathrm{f})(1)$. Thus, tax-exempt organizations foregoing the PAC option can avoid the section 527(f)(1) tax to the extent they have no investment income. $I d$.

${ }^{321}$ Current Treasury Regulations reserve the rules for taxation of expenditures allowed by FECA, which at the time of the reservation did not include independent expenditures, but, after Citizens United, does. Treas. Reg. § 1.527-6(b)(3) (1980); see also Aprill, supra note 18, at 392 (explaining that "Citizens United is understood to mean that section 501(c)(4), section 501(c)(5), and 501(c)(6) organizations may make independent expenditures"). Accordingly, the taxation of independent expenditures pursuant to section 527(f)(1) depends in part on the status of the reserved regulations. $I d$. (observing that "the regulations currently treat no expenditure permitted by the Federal Election Campaign Act as being for an exempt function subject to the section 527(f) tax" because a paragraph that 527(f) refers to, section 527(b)(3), is currently reserved).

${ }^{322}$ See Leff, supra note 250, at 715-23 (developing a regime for, among other things, determining how to allocate expenses to non-expenditure activities, such as endorsements). See also American Jobs Creation Act of 2004, H.R. 4520, 108th Cong. § 692(b) (as introduced in the House, June 4, 2004) (treating a set percentage of income as subject to tax for violations of the Political Activities Prohibition). 
i.e., it cannot realistically be allocated out. Accordingly, special rules or not, it may be impracticable to tailor a more appropriate penalty than the current one: loss of exempt status.

In addition, another potential pitfall with the taxing speech approach is whether it would raise new concerns about penalizing speech. Although more narrowly tailored than the current rule, it would be a tax on speech, which could have a chilling effect. Thus, for example, although a charity might no longer face loss of section 501(c)(3) status, each independent expenditure may have tax consequences, which to an organization with a baseline of taxexemption would still seem like a penalty. ${ }^{323}$

The taxing speech approach would also be an exception to the generally prevailing rule that charitable organizations may not engage in unlimited unrelated activity. ${ }^{324}$ Because the political activity was subject to tax, it would follow that it was not a "related" activity, even if such terminology were not used. Due to constitutional concerns, however, unlike other unrelated activities, the charity could engage in as much of it as desired, so long as taxes are paid. ${ }^{325}$ This runs counter to the very idea that a charitable organization should be organized and operated exclusively for charitable purposes. Further, as a practical matter, this approach does not avoid vagueness or line-drawing problems because it would still be necessary to distinguish between taxable speech and nontaxable speech. ${ }^{326}$

${ }^{323}$ Because of Citizens United, this is now an issue for noncharitable exempt organizations such as section 501(c)(4) organizations, which, after Citizens United, are subject to the section 527(f)(1) tax for independent expenditures. Aprill, supra note 18, at 392. Detailed discussion of this issue is, however, outside the scope of this Article. See id. at 391-401 (discussing the effect of Citizens United on noncharitable tax-exempt organizations). Additionally, if the baseline is more appropriately that of a taxable organization, then taxation of speech is not necessarily a penalty but just partial withdrawal of a benefit. Assuming that the proper baseline is that of a taxable organization, revocation of section 501(c)(3) status altogether, which is the current rule, is really just a difference of degree not of kind. Blanket revocation can and, as argued above, should be construed as total revocation of a benefit, and not as a penalty with constitutional dimensions. See supra Part II.C.

${ }^{324}$ See People's Educ. Camp Soc'y, Inc. v. Comm'r, 331 F.2d 923, 935 (2d Cir. 1964) (ruling that "feeder" organizations that provide funds to exempt organizations are taxable, despite their purpose to provide funds to nontaxable organizations).

${ }^{325}$ Political activity would thus be treated better than unrelated business activity, which also is subject to tax, and may not be unlimited because the organization would lose its taxexempt status. See, e.g., Rev. Rul. 69-220, 1969-1 C.B. 154 (deciding that a club was not exempt from taxes because it was not organized exclusively for nonprofit purposes); I.R.S. Gen . Couns. Mem. 39,108 (May 28, 1982) (examining the significance of an organization's source of income in determining tax exemption).

${ }^{326}$ Also affecting the analysis is whether the "subsidy" rationale for tax-exempt status is adopted. See supra Part III.C for a discussion of the subsidy rationale. If not, then a taxing speech approach should in theory be based on something other than tailoring the penalty to the activity subsidized. 


\section{Much Ado About Nothing? It Depends on the Deduction.}

Notwithstanding these objections, of the alternatives to the Political Activities Prohibition, a taxing speech approach probably is the best. ${ }^{327}$ It does not involve arbitrary limits on the amount of political activity and does not require related-unrelated distinctions. Organizations that argue that political intervention is connected to, if not required by, the organization's mission likely would be satisfied, especially (and ironically) because it would be difficult to impose a loss of tax benefit with respect to endorsements or other types of speech where there is no obvious expenditure. Thus, the "true" charities, or those with substantial nonpolitical activities, that want to dabble in politics would be able to participate in a meaningful way in political campaigns.

Further, for those concerned about charities becoming too immersed in politics, there would be real disincentives to political activity. Political activity expenses, such as independent expenditures, would likely have tax consequences. In addition, as discussed in Part I, although endorsements and other types of campaign intervention might not carry tax consequences, they would present their own perils: most pertinently, that of alienating the organization's own constituency. ${ }^{328}$

But even if all this were an acceptable solution, there remains another critical issue: the charitable deduction. ${ }^{329}$ If the present law approach to the charitable deduction is retained, ${ }^{330}$ which appears to present negligible constitutional concerns, the change to the exemption rules might be much ado about nothing. This is because charities that value the charitable deduction would refrain from engaging in political activity. Further, political organizations that might be tempted to become charity PACs (i.e., political organizations disguised as charities) would lose a reason to organize as a charity. ${ }^{331}$ Accordingly, unless the charitable deduction rules

\footnotetext{
327 This is not an endorsement of the approach, however.

${ }^{328}$ See supra note 105 and accompanying text.

${ }^{329}$ Other tax benefits, such as receipt of tax-exempt financing are also important to consider. See supra note 277.

${ }^{330}$ That approach contains no such deduction to organizations that engage in political activity, I.R.C. § 170(c)(2)(D) (2006), and, as noted in Part III.B, presents little constitutional concerns.

${ }^{331}$ The allure of branding political speech under the section 501(c)(c) moniker might be significant, even without the charitable deduction. And there could still be other incentives, namely more favorable disclosure rules. Charities, other than private foundations, are not required to publicly disclose donors, as are political organizations. I.R.C. § 6104(d)(3). This highlights another change that would have to be debated, whether the disclosure rules for charities should be changed if political activity is allowed. This would become part of the ongoing debate about disclosure. See H.R. 5175, 111th Cong. (as introduced in the House, June
} 
were modified to allow charitable contributions to charities that engage in political activity, changes to the exemption rules might not achieve the goal. ${ }^{332}$

One might respond then that the charitable deduction rules therefore should also be changed. And therein lies the rub. Here, there are two approaches. One is just to make a blanket change to the policy of the charitable deduction, and provide that a charitable deduction is available irrespective of the political activity of charities. But although Congress has the power to take such action, it is highly doubtful that it would. The revenue consequences likely would be significant. Arguably, such a change would result in a lot of new charitable contributions, especially as the change would encourage formation of new politically-oriented section 501(c)(3) organizations. Further, apart from revenue concerns, Congress might simply not opt for a policy that would encourage political activity by charities and further dilute the meaning of charitable purpose. In addition, there is a real risk of "charity capture." Major donors might make large charitable contributions with political intent, and subject charities to their political preferences, thus driving the charity's political activity.

Another option would be to attempt to retain coherence between the charitable exemption and the charitable deduction, and follow through on the taxing speech approach in the charitable deduction context. This would continue the policy of nonsubsidy for political activity and discourage donors from making contributions for political purposes. Under such an approach, there would be some disallowance of the charitable deduction to the extent that an organization engages in political activity. Thus, a regime could be established to deny a portion of a charitable deduction to donors with respect to contributions made to organizations that engage in political activity, in proportion to such activity. ${ }^{333}$ Or, in the alternative, the deduction would be allowed but the organization would pay a proxy tax on the amount of subsidy provided by the charitable deduction. ${ }^{334}$

28, 2010) (proposing additional disclosure requirements with respect to spending in Federal elections).

${ }^{332}$ But section 501(c)(3) could be attractive for gift tax purposes because contributions to section 501(c)(3) organizations are exempt from the gift tax whereas contributions to other section 501(c) organizations do not have an explicit exemption. I.R.C. § 2522(a)(2). Whether, for example, gifts to section 501(c)(4) organizations are exempt from gift tax is a subject of considerable debate. See Aprill, supra note 18, at 384-385 (discussing the various positions that have been taken regarding the gift tax and gifts to section 501(c)(4) organizations).

${ }^{333}$ For example, if a donor made a contribution of $\$ 100$ to a charity, 10 percent of the activities of which were political activity, the donor would be allowed a deduction of $\$ 90$ instead of the full $\$ 100$.

${ }^{334}$ Such an approach would be similar to present-law rules that ensure that otherwise 
The need for such a proxy tax regime, however, further magnifies the problem, discussed above, of valuing the subsidy (here, the amount of a charitable contribution that should be disallowed) for political activities that do not have readily assignable expenses, such as endorsements. To the extent such activities cannot be readily captured, deductible political donations for such political activity likely would be an enormous loophole. Thus, a serious risk of charity capture, and substantial revenue loss, would remain.

\section{E. Summary}

In short, alternatives to the status quo, whether constitutionally mandated or not, are unappealing. The alternatives range from the extreme of unlimited political activity to drawing arbitrary lines regarding the amount of permitted political activity. The former would undermine the meaning of charity, by inviting political purposes into the fold. The latter alternatives involve difficult linedrawing exercises that offer little-to-no improvement over present law but without the benefits of the present Rule. Arguably, the best alternative is taxing political activity, which would address the putative "penalty effect" of the Political Activities Prohibition by tailoring the penalty to the political activity. But even that might have little practical impact absent corresponding changes to the charitable deduction. And those changes in turn would likely leave the gaping and undesirable loophole of politically motivated contributions and political capture of charities by major donors.

\section{CONCLUSION}

Citizens United makes a Supreme Court challenge to the Political Activities Prohibition likely and a reexamination of the political speech of charities necessary. This Article has argued that although the Political Activities Prohibition has flaws, it has largely been a noncontroversial rule that serves important purposes. Most critically, the prohibition draws an important line that acts as one of the few limitations on the charitable purpose requirement. Because of the

deductible membership dues paid by businesses to exempt organizations, such as trade associations that engage in nondeductible lobbying activity, either are not deducted or, if deducted, tax is paid to the extent of the value of the deduction. I.R.C. $\S 6033(\mathrm{e})$. It already has been proposed in Congress that the proxy tax regime be extended to the lobbying activities of section 501(c)(3) organizations in order to deny the charitable deduction with respect to a charity's lobbying activity. MinORITY StafF OF S. COMM. ON FinANCE, 109TH Cong., InVESTIGATION OF JACK ABRAMOFF'S USE OF TAX-EXEMPT ORGANIZATIONS 54 (Comm. Print 2006). 
prohibition, charities are not allowed to get involved in politics, which gives the charitable purpose requirement clarity and keeps the "independent" sector independent.

Although the risks of loosening the prohibition may be overstated, the gains from doing so are not apparent. There is real, if intangible, benefit to a charitable sector that is noble in purpose and free of partisan rancor. Further, there is no easy alternative to the Political Activities Prohibition. Accordingly, this Article has argued that the Political Activities Prohibition should be retained.

Of course, retention of the Rule would not be possible if it were unconstitutional. Although Citizens United presents a challenge to the constitutionality of the prohibition, close analysis of the case results in several meaningful and critical distinctions that could and should lead to the conclusion that the Political Activities Prohibition is not, for constitutional purposes, a burden on speech. This is not to say that present law is perfect-it is not. But the prohibition represents the evolution of a century of wrestling with the subject of political activity and charity, and the wisdom that the two are not compatible. Such wisdom should not be contravened. 